\title{
Bactericidal and In-Vitro Cytotoxic Efficacy of Silver Nanoparticles (Ag-NPs) Fabricated by Endophytic Actinomycetes and Their Use as Coating for the Textile Fabrics
}

\author{
Salem S. Salem ${ }^{1}{ }^{\mathbb{D}}$, Ehab F. EL-Belely ${ }^{1}{ }^{\mathbb{D}}$, Gniewko Niedbała $^{2}{ }^{\mathbb{O}}$, Maryam M. Alnoman ${ }^{3}$,

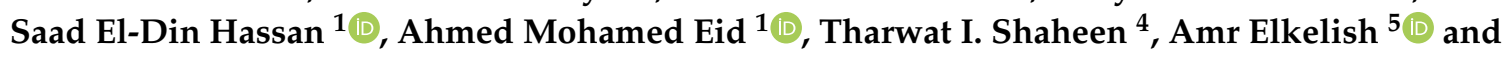 \\ Amr Fouda $1, *$ (1) \\ 1 Department of Botany and Microbiology, Faculty of Science, Al-Azhar University, Nasr City, \\ Cairo 11884, Egypt; salemsalahsalem@azhar.edu.eg (S.S.S.); elbelely@azhar.edu.eg (E.F.E.-B.); \\ Saad.el-din.hassan@umontreal.ca (S.E.-D.H.); aeidmicrobiology@azhar.edu.eg (A.M.E.) \\ 2 Department of Biosystems Engineering, Faculty of Environmental Engineering and Mechanical Engineering, \\ Poznań University of Life Sciences, Wojska Polskiego 50, 60-627 Poznań, Poland; gniewko@up.poznan.pl \\ 3 Biology Department, Faculty of Science, Taibah University, Al-Sharm, Yanbu El-Bahr 46429, Saudi Arabia; \\ mnaaman@taibahu.edu.sa \\ 4 National Research Centre, El-Behouth St., Dokki, Giza 12622, Egypt; ti.shahin@nrc.sci.eg \\ 5 Botany Department, Faculty of Science, Suez Canal University, Ismailia 41522, Egypt; \\ amr.elkelish@science.suez.edu.eg \\ * Correspondence: amr_fh83@azhar.edu.eg; Tel.: +20-111-335-1244
}

Received: 1 October 2020; Accepted: 17 October 2020; Published: 21 October 2020 updates

\begin{abstract}
An endophytic strain of Streptomyces antimycoticus L-1 was isolated from healthy medicinal plant leaves of Mentha longifolia L. and used for the green synthesis of silver nanoparticles (Ag-NPs), through the use of secreted enzymes and proteins. UV-vis spectroscopy, Fourier-transform infrared (FT-IR), transmission electron microscopy (TEM), X-ray diffraction (XRD), and dynamic light scattering (DLS) analyses of the Ag-NPs were carried out. The XRD, TEM, and FT-IR analysis results demonstrated the successful biosynthesis of crystalline, spherical Ag-NPs with a particle size of 13-40 nm. Further, the stability of the Ag-NPs was assessed by detecting the surface Plasmon resonance (SPR) at $415 \mathrm{~nm}$ for one month or by measuring the NPs surface charge $(-19.2 \mathrm{mV})$ by

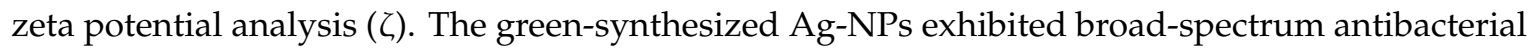
activity at different concentrations (6.25-100 ppm) against the pathogens Staphylococcus aureus, Bacillus subtilis Pseudomonas aeruginosa, Escherichia coli, and Salmonella typhimurium with a clear inhibition zone ranging from $(9.5 \pm 0.4) \mathrm{nm}$ to $(21.7 \pm 1.0) \mathrm{mm}$. Furthermore, the green-synthesized Ag-NPs displayed high efficacy against the Caco-2 cancerous cell line (the half maximal inhibitory concentration $\left.\left(\mathrm{IC}_{50}\right)=5.7 \pm 0.2 \mathrm{ppm}\right)$. With respect to antibacterial and in-vitro cytotoxicity analyses, the Ag-NPs concentration of $100 \mathrm{ppm}$ was selected as a safe dose for loading onto cotton fabrics. The scanning electron microscopy connected with energy-dispersive X-ray spectroscopy (SEM-EDX) for the nano-finished fabrics showed the distribution of Ag-NPs as $2 \%$ of the total fabric elements. Moreover, the nano-finished fabrics exhibited more activity against pathogenic Gram-positive and Gram-negative bacteria, even after 10 washing cycles, indicating the stability of the treated fabrics.
\end{abstract}

Keywords: endophytic actinomycetes; Ag-NPs; green synthesis; streptomyces spp.; cotton fabrics; antibacterial and cytotoxicity activities 


\section{Introduction}

Nanotechnology is a promising field with the potential for integration into various industrial and biotechnological sectors, such as pharmaceuticals, agriculture, cosmetics, biodegradation, and wastewater treatment [1-4]. Nanoparticles (NPs) are referred to as those particles with a size ranging between 1 and $100 \mathrm{~nm}$ and with distinctive physico-chemical properties [5-7]. There are many different approaches to the fabrication of NPs, including physical, chemical, and biological methods [8-10]. Recently, due to the spread of infections in hospitals amongst both patients and medical staff, it has become urgent to develop medical textiles based on nanotechnology in order to provide smart properties such as resistance to pathogenic microbes and UV protections [11,12].

Silver nanoparticles (Ag-NPs) can be synthesized by chemical, physical, and biological methods, where the latter remains the most widely accepted and popular, due to its fast, simple, cost-effective manner, which avoids the use of hazardous chemicals and is free of hazardous by-products [13,14]. Biological synthesis of Ag-NPs can be accomplished by plants, bacteria, fungi, yeast, and actinomycetes $[9,15]$. Ag-NPs can be incorporated into several industrial sectors, such as medicine, pharmaceuticals, biomolecular detections, food production, agriculture, and the textile industry, due to their chemical stability, biocompatibility, catalytic activity, high conductivity, and inherent medicinal properties [1]. Furthermore, Ag-NPs are preferred over the other metal or metal oxide NPs in the textile industry, due to their high stability under UV illumination and high temperatures [16]. During textile manufacturing, Ag-NPs can be added as additives to the spinning processes used for fiber manufacture or can be utilized as a final agent for the finished textile [17,18].

Endophytes are the organisms including bacteria, fungi, and actinomycetes that can colonize internal plant tissues without invoking any adverse symptoms [19]. Endophytic microbes, especially actinomycetes, are characterized by a huge number of their metabolites, which can be utilized as reducing, capping, and stabilizing agents in the fabrication of NPs [20]. Different species of actinomycetes are used as biocatalyst for fabrication of Ag-NPs such as Streptacidiphilus durhamensis HGG16n [21], Streptacidiphilus sp. CGG11n [22], Streptomyces noursei H1-1 [9], Streptomyces spp. [23]. Ag-NPs have distinctive antimicrobial qualities which make them efficient at different particle sizes and concentrations versus a wide spectrum of Gram-negative and Gram-positive pathogens, including multidrug-resistant and biofilm-forming bacteria [24,25]. Moreover, biogenic silver nanoparticles have been extensively used as anticancer agents for the clinical management of cancer, as mediated through a cytotoxic effect due to induced oxidative stress, reducing the viability and modifying the morphology of cancer cells. Recently, many reports have focused on the potent anticancer effects of green silver nanoparticles against colon, brain, kidney, intestinal, hepatic, epidermoid, gastronomic, laryngeal, lung, and cervical cancer cell lines [26].

Therefore, in this study, we explore the efficacy of endophytic Streptomyces antimycoticus isolated from healthy leaves of medicinal plant Mentha longifolia L. as a bioreactor for the biological synthesis of Ag-NPs. The characteristics of the biosynthesized Ag-NPs are evaluated, as well as their biological activities, including antibacterial activity and cytotoxicity. Finally, a safe dose of Ag-NP coating dose, which may provide new features for fabrics, is defined.

\section{Materials and Methods}

\subsection{Sample Collection}

Healthy leaves of Mentha longifolia L. plants (family: Labiatae) were collected from the Rihibat Nada site (28.538664 N and 33.921423E), Saint Katherine, South Sinai, Egypt. Plant samples were placed in sterile polythene bags, transported to the laboratory in an icebox, and processed within $24 \mathrm{~h}$. Plant identification was achieved in the herbarium of Botany and Microbiology Department, Al-Azhar University, Cairo, Egypt. 


\subsection{Isolation of Endophytic Actinomycetes}

Surface sterilization of plant leaves was carried out by applying the five-step method described by Fouda et al. [27]. Sterilized leaves were cut into pieces $(1 \mathrm{~cm} \times 1 \mathrm{~cm})$, plated onto starch casein agar (SCA) [28], supplemented with nalidixic acid $\left(50 \mu \mathrm{g} \mathrm{mL}{ }^{-1}\right)$ and nystatin $\left(25 \mathrm{mg} \mathrm{mL}^{-1}\right)$, and incubated at $30{ }^{\circ} \mathrm{C}$ for 4 weeks. Colonies that arose from inside plant pieces and exhibited actinomycete morphologies were purified and preserved in SCA slants for further analyses.

\subsection{Molecular Identification of Actinomycetes Isolates}

The purified cells of isolated endophytic actinobacteria were washed in saline solution $(\mathrm{NaCl}$, 0.085\%). Genomic DNA was extracted using the GeneJET Purification Kit (Thermo K0721, Thermo Fisher Scientific Inc., Ottawa, ON, Canada). Then, 16S-rRNA genes were amplified using Maxima Hot Start PCR Master Mix (Thermo K1051, Thermo Fisher Scientific Inc., Ottawa, ON, Canada) in $50 \mu \mathrm{L}$ reactions using the universal primers of 27f (5'-AGA GTT TGA TCC TGG CTC AG-3') and 1492r (5'-TAC GGC TAC CTT GTT ACG ACT-3') [29]. PCR products were purified using a Gene-JET ${ }^{\mathrm{TM}}$ PCR Purification Kit (Thermo K0701), and then were sequenced on GATC Company (Ebersberg, Germany) with an ABI 3730xl DNA sequencer using the forward and reverse primers. The bacterial $16 \mathrm{~S}$ sequences in this study were deposited in GenBank under the accession number MT534272. The obtained sequences and those of their most closely related taxa retrieved from GenBank were aligned using the CLUSTAL X program [30]. Phylogenetic distances were calculated using Kimura's two-parameter model [31], evolutionary trees were inferred using the neighbor-joining method [32], and the phylogenetic tree was created using the MEGA v6.1 software, with confidence testing by bootstrap analysis (1000 repeats).

\subsection{Extracellular Biosynthesis of Silver Nanoparticles (Ag-NPs)}

Ag-NPs were biologically synthesized by using pure $\mathrm{AgNO}_{3}$ (Sigma-Aldrich) as a metal precursor, with the biomass filtrate of isolated actinobacteria as the reducing agent.

Practically, three disks $(0.8 \mathrm{~mm})$ of freshly grown cultures of the isolated endophytic actinobacteria were inoculated into $100 \mathrm{~mL}$ of starch casein broth (SCB) media and incubated at $(30 \pm 2){ }^{\circ} \mathrm{C}$ for $96 \mathrm{~h}$ in an orbital shaker (180 rpm). Then, the actinomycetes biomass was harvested, by passing the SCB media through four layers of compact gauze. The biomass obtained was washed with sterile distilled water, in order to remove leftovers from the growth media. The washed biomass was suspended in $100 \mathrm{~mL}$ of distilled water at $(30 \pm 2)^{\circ} \mathrm{C}$ for $72 \mathrm{~h}$. After incubation, the mixture was filtered through filter paper (Whatman No. 1) in order to obtain the biomass filtrate, which was used as the reducing agent for the biogenic synthesis of Ag-NPs as follows:

First, $1 \%(v / v)$ of $1 \mathrm{mM} \mathrm{AgNO} 3$ was added to $100 \mathrm{~mL}$ of the biomass filtrate and incubated for 24 h., at $(30 \pm 2){ }^{\circ} \mathrm{C}$ in dark and static conditions. The $\mathrm{pH}$ of the mixture was adjusted to 9 by $1 \mathrm{~N}$ $\mathrm{NaOH}$, which was added in a drop-wise manner under stirring conditions. Actinomycetes biomass filtrate and $\mathrm{AgNO}_{3}$ were also used as controls. The synthesis of Ag-NPs was preliminarily examined by a color change from colorless into dark or yellowish-brown and optical density measurements in the range (300-700) nm (JENWAY 6305 Spectrophotometer,230 V/50 Hz, Staffordshire, UK) [33]. The surface Plasmon resonance (SPR) for biogenic Ag-NPs was detected after intervals (1, 3, 7, 14, and 30) days, in order to check the stability of NPs. The biomass filtrate was used as blank for the JENWAY 6305 Spectrophotometer.

\subsection{Characterization of Biosynthesized Ag-NPs}

The shapes and sizes of the biogenic Ag-NPs were identified by transmission electron microscopy (TEM-JEOL 1010, Tokyo, Japan). Briefly, a drop of NPs suspension solution was put on a carbon-coated copper TEM grid. Extra NP solution on the TEM grid was eliminated by touching it to blotting paper. The grid was then kept at room temperature for drying [34]. The binding properties of silver 
nanoparticles were investigated by FT-IR analysis (Agilent system Cary 630 FTIR model, USA) in the range $400-4000 \mathrm{~cm}^{-1}$. The X-ray diffraction (XRD) patterns of silver nanoparticles were analyzed using Shimadzu Scientific Instruments (SSI), Kyoto, Japan. The X-Ray diffraction types of Ag-NPs were obtained with the XRD-6000 series, including residual austenite quantitation, stress analysis, crystallite size/lattice strain, crystallinity calculation, and materials analysis by overlaid XRD (Shimadzu apparatus) with nickel filter and $\mathrm{Cu}-\mathrm{Ka}$ target. The $2 \theta$ values were measured in a range from $4^{\circ}$ to $90^{\circ}$. The NPs sizes obtained from XRD analysis were estimated by Scherrer's formula:

$$
\mathrm{D}=0.94 \lambda / \beta \cos \theta
$$

where $D$ is the mean particle size, 0.94 is the Scherrer's constant, $\lambda$ is the $X$-ray wavelength, $\beta$ is the half of the maximum intensity, and $\theta$ is the Bragg's angle.

Furthermore, investigation of the distribution, size, and poly-dispersity index (PDI) of biogenic Ag-NPs in the colloidal solution was carried out using a dynamic light scattering (DLS) technique. The biogenic Ag-NPs were suspended in distilled $\mathrm{H}_{2} \mathrm{O}$ and exposed to a Zeta sizer nano-series (Nano ZS, Malvern, UK). Furthermore, the stability of actinobacterial mediated Ag-NPs synthesis was analyzed using Zeta Potential measurement.

\subsection{Antibacterial Activity of Ag-NPS}

The antibacterial activity of the biogenic Ag-NPs was examined against five selected bacterial pathogens: two Gram-positive strains (Bacillus subtilis ATCC 6633 and Staphylococcus aureus ATCC 6538) and three Gram-negative strains (Salmonella typhimurium ATCC 14028, Pseudomonas aeruginosa ATCC 9022 and Escherichia coli ATCC 8739). Freshly grown cultures of the selected bacterial strains were individually prepared in sterile saline solutions at a concentration of $\left(1.5 \times 10^{8}\right) \mathrm{CFU} / \mathrm{mL}$, seeded in Mueller-Hinton agar media. According to the agar well diffusion method, 3 wells $(0.8 \mathrm{~cm}$ diameter $)$ were cut in the seeded Mueller-Hinton plates and $100 \mu \mathrm{L}$ of Ag-NPs (100 ppm) was added into each well. The plates were kept in the refrigerator for $1 \mathrm{~h}$, then incubated for $24 \mathrm{~h}$ at $37^{\circ} \mathrm{C}$. The diameter of the potential growth inhibition zones around each well was recorded (mm). Different Ag-NP concentrations $(6.25,12.5,25.0,50.0$, and $75.0 \mathrm{ppm})$ were prepared, in order to determine the minimum inhibitory concentration (MIC) against each bacterial pathogen [35]. The experiments were carried out in triplicates.

\subsection{Cytotoxic Activity of Ag-NPs Against Cancer and Normal Cells}

The potential cytotoxicity of the actinobacterial-synthesized Ag-NPs was assessed by the MTT [3-(4, 5-dimethylthiazol-2-yl)-2, 5-diphenyl tetrazolium bromide] assay using human colorectal adenocarcinoma cells (Caco-2) and normal Vero cells (kidney of African green monkey) procured from ATCC. These cancerous and normal cell lines were chosen as a model for cancerous and normal cell lines, respectively. The cells were cultured in 96-well plates at a concentration of $\left(1 \times 10^{5}\right)$ cells/well and treated with double-fold dilutions of the biologically synthesized Ag-NPs (3.9-1000 $\mu \mathrm{g} / \mathrm{mL})$. After $48 \mathrm{~h}$ of incubation, morphological changes that occurred in epithelial cells as a result of treatment with silver nanoparticles were monitored using an inverted light microscope (Nikon, Tokyo, Japan). For the MTT assay, cancer and normal cells were grown in 96-well plates at $\left(1 \times 10^{5}\right)$ cells/well and treated with a series of double-fold concentrations $(3.9-1000 \mu \mathrm{g} / \mathrm{mL})$ of the biogenic Ag-NPs and incubated at $37^{\circ} \mathrm{C}$ for $48 \mathrm{~h}$. MTT ( $5 \mathrm{mg} / \mathrm{mL}$ in phosphate-buffered saline) was added to each well and incubated at $37^{\circ} \mathrm{C}$ for $1-5 \mathrm{~h}$ at $37^{\circ} \mathrm{C}$ with $5 \%$ carbon dioxide. A purple formazan crystal was formed, which was dissolved by adding dimethyl sulfoxide (10\%). Plates were kept in a plate shaker for $30 \mathrm{~min}$ in the dark. Finally, the optical density of the samples was measured using a multi-well ELISA plate reader at $560 \mathrm{~nm}$ [36]. The percentage of cell viability was calculated using the following formula:

Cell viability $\%=($ sample absorbance/control absorbance $) \times 100$. 


\subsection{Application of Ag-NPs for Medical Fabrics}

\subsubsection{Loading the Biogenic Ag-NPs onto the Cotton Textile Using the Pad-Dry-Cure Method}

Cotton fabrics were washed with warm water and dried. The cotton textile was then cut into pieces $(15 \mathrm{~cm} \times 30 \mathrm{~cm})$ and soaked in an aqueous solution of biogenic Ag-NPs (at a safe concentration based on the cytotoxicity tests). For the subsequent processing of fabrics with colloidal silver, the solution was constantly stirred. Fabric samples were immersed in the colloidal bath for 1 min and then thoroughly squeezed under constant pressure using a laboratory pad. Then, the samples were dried at $70{ }^{\circ} \mathrm{C}$ for $3 \mathrm{~min}$, and ironed at $150{ }^{\circ} \mathrm{C}$ for $2 \mathrm{~min}$. The experiment was conducted using the following treatments: (1) non-processed fabrics as a control, (2) fabrics treated with Ag-NPs, and (3) fabrics treated with Ag-NPs and washed five or ten repeated wash cycles. Each washing cycle lasted 45 min in a warm-water washing machine containing $2 \%$ sodium carbonate. At the end of the washing cycle, the fabric was dried in a dryer at $80{ }^{\circ} \mathrm{C}$.

\subsubsection{Scanning Electron Microscopy for Nanocoated Fabrics}

The surface characteristics of the treated fabrics and their metal nanoparticle contents were evaluated using SEM (JSM-5400, JEOL, Tokyo, Japan) coupled with energy-dispersive X-ray spectroscopy (EDX).

\subsubsection{Antibacterial Activity of Nano-Coated Fabrics}

The antibacterial potential of nano-coated fabrics was assessed against bacterial pathogens: Gram-positive strains (Bacillus subtilis ATCC 6633 and Staphylococcus aureus ATCC 6538) and Gram-negative strains (Pseudomonas aeruginosa ATCC 9022 and Escherichia coli ATCC 8739). Each bacterial pathogen was seeded into Mueller-Hinton agar media and left to solidify. Then, $1 \mathrm{~cm}$ squares of each fabric sample were aseptically prepared, and put onto the agar surface, and incubated for one day. After incubation, the plates were examined, and the diameters of the growth inhibition zones $(\mathrm{mm})$ were recorded around the fabric samples. The experiment was carried out using the following treatments: (1) untreated fabrics as a control, (2) fabrics treated with Ag-NPs, and (3) fabrics treated with Ag-NP and washed 5 and 10 repeated wash cycles.

\subsection{Statistical Analysis}

All results presented in this study are the means of three independent replicates. Data were subjected to analysis of variance (ANOVA) by the statistical package SPSS v17. The mean difference comparison between the treatments was analyzed by the Tukey HSD test at a significance level of $p \leq 0.05$.

\section{Results and Discussion}

\subsection{Isolation and Molecular Identification of Endophytic Actinomycetes}

Medicinal plants are considered as adequate shelters for several endophytic microbes, including bacteria, fungi, and actinomycetes [14]. Therefore, the isolation of these endophytic microbes, especially from plants inhabiting harsh environments, opens up promising strategies for different biotechnological applications. In this study, an endophytic actinobacterial isolate of L-1 was obtained from healthy leaves of Mentha longifolia L.; based on BLAST analysis, the endophytic actinomycetes isolate obtained in this study was identified as Streptomyces antimycoticus L-1, with similarity percentage of $98 \%$ related to Streptomyces antimycoticus (accession number: NR_041080). The phylogenetic tree of 16S rRNA sequences showed homology of the obtained sequence to Streptomyces antimycoticus with a bootstrap percentage of more than $90 \%$ (Figure 1). To the best of our knowledge, this is the first report of the isolation of Streptomyces antimycoticus from the medicinal plant M. longifolia for use as a biocatalyst for Ag-NPs synthesis. 


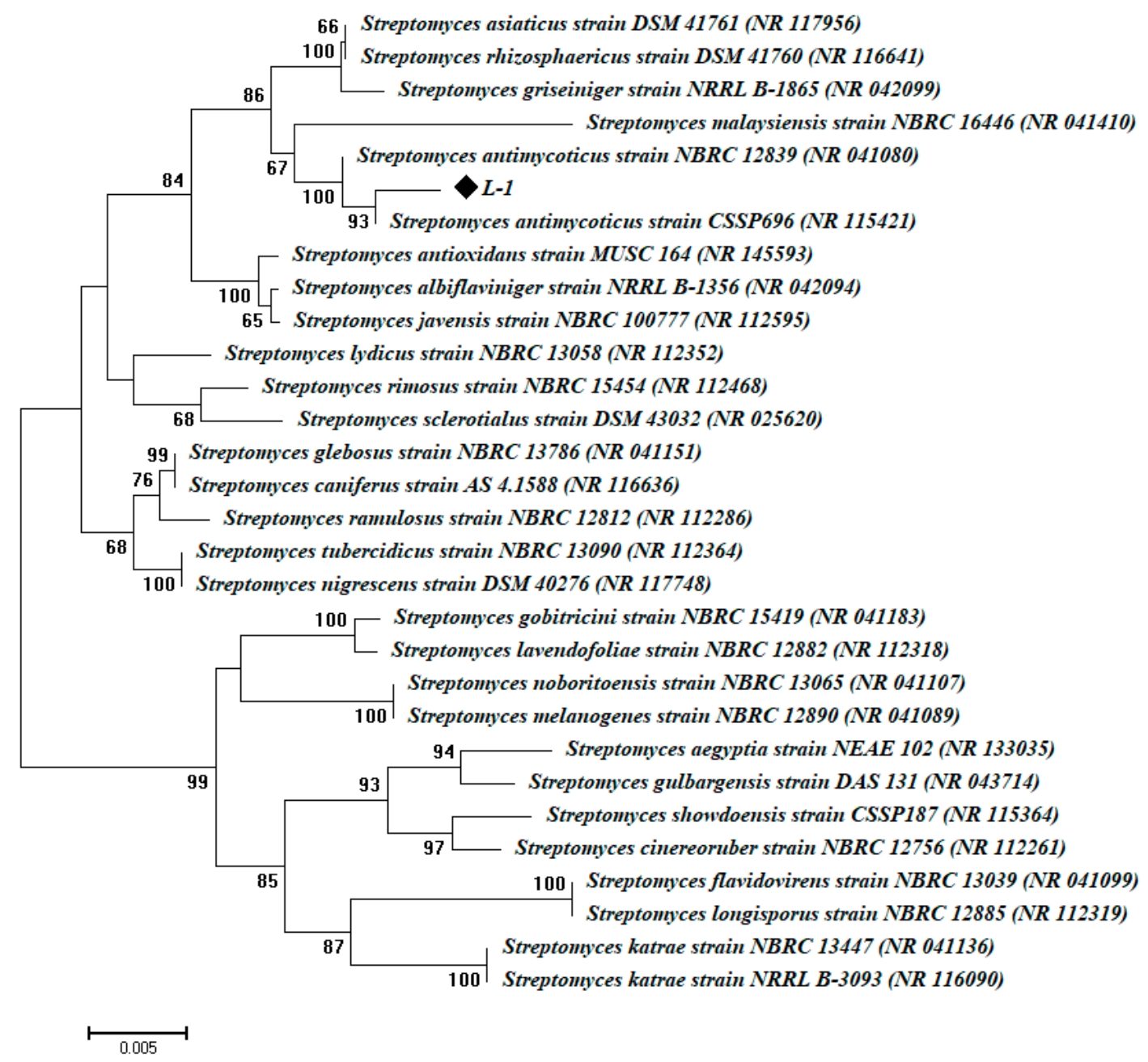

Figure 1. Phylogenetic tree of Streptomyces antimycoticus based on $16 \mathrm{~S}$ rRNA sequences analysis. The symbol indicates to 16S rRNA fragments of the endophytic actinomycetes strain obtained in the current study. The analysis was completed with MEGA 6 using the neighbor-joining method.

\subsection{Biogenic Synthesis of Ag-NPs}

The biogenic fabrication of the nanoscale particles is preferable to physical and chemical processes, due to its properties of energy efficiency, ease of scaling-up, low coast, low toxicity, and biocompatibility. Therefore, biogenic nanoparticles can be safely exploited in many biological applications [37]. The actinomycetes, particularly Streptomyces, are some of the best candidates for the large-scale biological fabrication of nano-sized materials, as a result of its cost-effectiveness due to its rapid growth, high biomass production, and environmental friendliness [38]. Furthermore, actinobacterial endophytes extracellularly produce active metabolites, such as enzymes and proteins, which may participate in the synthesis of nanoparticles [20].

In this work, an aqueous solution of $\mathrm{AgNO}_{3}(1 \mathrm{mM})$ was added to the washed actinomycetal biomass filtrate. The reaction mixture turned into a yellowish-brown suspension (Figure 2B-D) due to the surface plasmon resonance, confirming the reduction of $\mathrm{Ag}^{+}$ions into nanoscale silver particles. The endophytic actinomycetes biomass filtrate and $\mathrm{AgNO}_{3}$ solution did not show any color change after the same incubation period. The reduction efficacy could be attributed to the liberated electron from reducing $\mathrm{NO}_{3}$ to $\mathrm{NO}_{2}$ and then $\mathrm{Ag}^{+}$to $\mathrm{Ag}^{0}$; therefore, the color intensity (in most cases) was related to the number of reduced $\mathrm{Ag}$ ions [34]. 

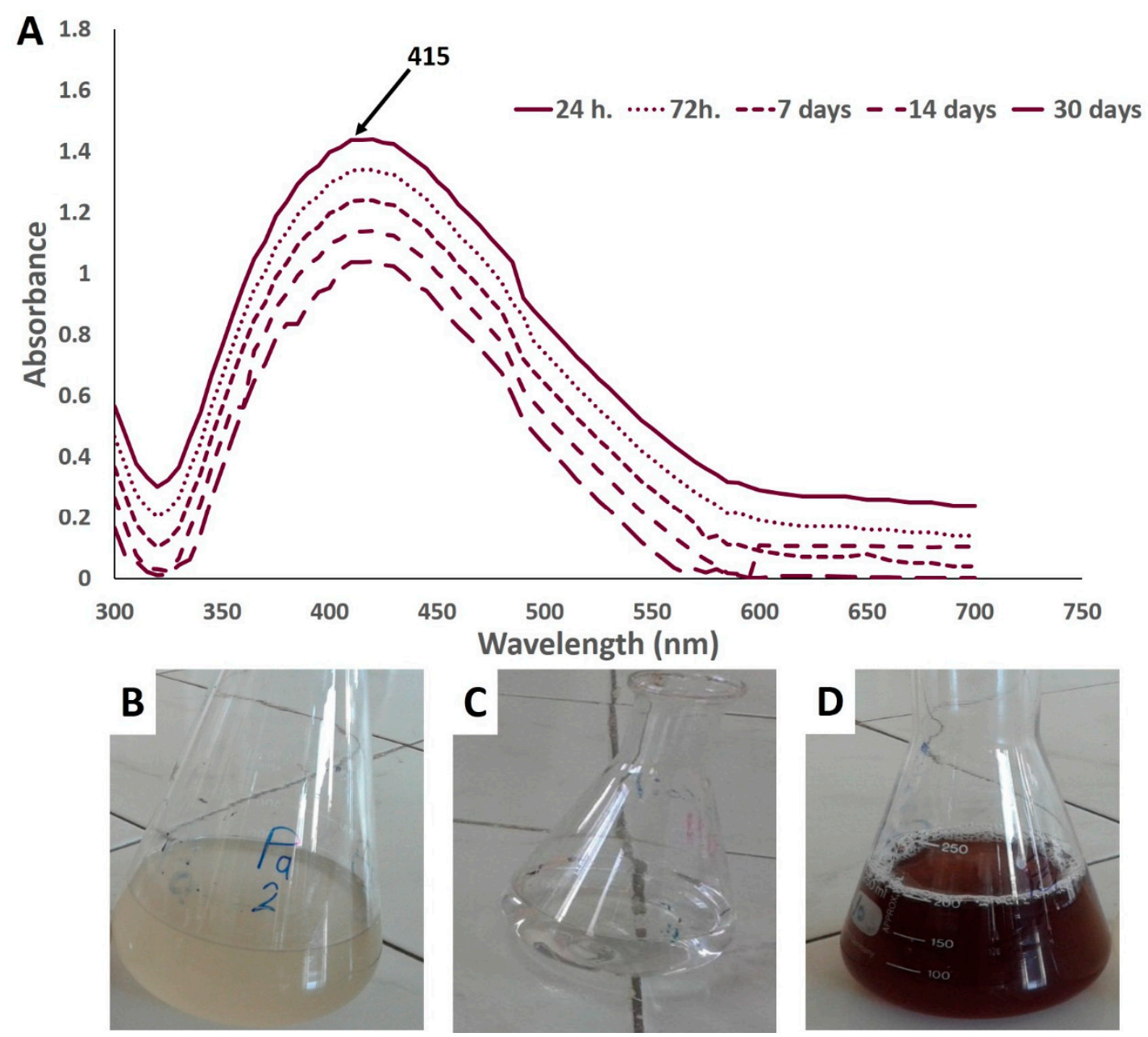

Figure 2. UV-vis spectroscopic analysis and color change of silver nanoparticles (Ag-NPs) synthesized by endophytic S. antimycoticus L-1: (A) UV-Vis spectra of Ag-NPs at different interval times; (B) biomass filtrate color; (C) silver nitrate solution; (D) yellowish-brown color of Ag-NPs synthesized by S. antimycoticus L-1.

\subsection{Characterization of Biosynthesized Silver Nanoparticles}

\subsubsection{UV-Vis Spectroscopy}

According to UV-vis spectroscopy of the mixture after $24 \mathrm{~h}$ of incubation, the maximum observed peak in this study was at $415 \mathrm{~nm}$, which is closely related to spherically shaped NPs [39]. The optimum peaks for green-synthesized Ag-NPs are in the range of 400-460 nm, which is the corresponding absorption range of SPR for Ag-NPs (Figure 2A) [40,41]. The brownish or yellowish-brown color is formed as a result of excitation of surface plasmon resonance, which is particular for Ag-NPs as recommended previously $[9,21,42]$. The previous studies reported that the surface plasmon resonance showed at $420 \mathrm{~nm}$ is usually related to nano-size from $2 \mathrm{~nm}$ to $100 \mathrm{~nm}[21,43]$. To check the stability of the NPs solution, the SPR for Ag-NPs synthesized by endophytic Streptomyces antimycoticus L-1 did not exhibit any change over different interval times, which confirmed the long-term stability of the biosynthesized Ag-NPs (Figure 2A).

\subsubsection{FT-IR Analysis}

The FT-IR analysis gives orientation information related to the structure of molecules. Figure 3 showed the FT-IR spectra of biosynthesized Ag-NPs at wavenumber range from $4000-400 \mathrm{~cm}^{-1}$. However, many functional groups that played roles in the reduction and capping of the biogenic 
Ag-NPs were present. The broad band at $3402.0 \mathrm{~cm}^{-1}$ is corresponded to $\mathrm{O}-\mathrm{H}$ and NH stretching vibrations, which were overlapped [44,45]; while the peak at $2931.0 \mathrm{~cm}^{-1}$ was assigned to $\mathrm{CH}$ aliphatic stretching of hydrocarbon [46,47]. The two peaks at $1635.0 \mathrm{~cm}^{-1}$ and $1561.0 \mathrm{~cm}^{-1}$ were related to $\mathrm{C}=\mathrm{O}$ stretching overlapped with amine-bending vibration [46,47]. The peaks at $2370.0 \mathrm{~cm}^{-1}$ and $2341.0 \mathrm{~cm}^{-1}$ were related to carbon dioxide peaks, adsorbed onto the protein surface [48]. The peak at $1384.0 \mathrm{~cm}^{-1}$ was assigned to $\mathrm{C}-\mathrm{N}$ and $-\mathrm{OH}$ bending vibrations [49], which was also emphasized by the two peaks at $1148.0 \mathrm{~cm}^{-1}$ and $1084.0 \mathrm{~cm}^{-1}$ which are associated with C-C, C-N stretching, as well as symmetric C-O stretching [50]. The peaks at $873.0 \mathrm{~cm}^{-1}$ and $665.0 \mathrm{~cm}^{-1}$ were related to $\left(\mathrm{CH}_{2}\right)$ n-rocking, associated with out-of-plane $\mathrm{OH}$ bending $[49,51]$.

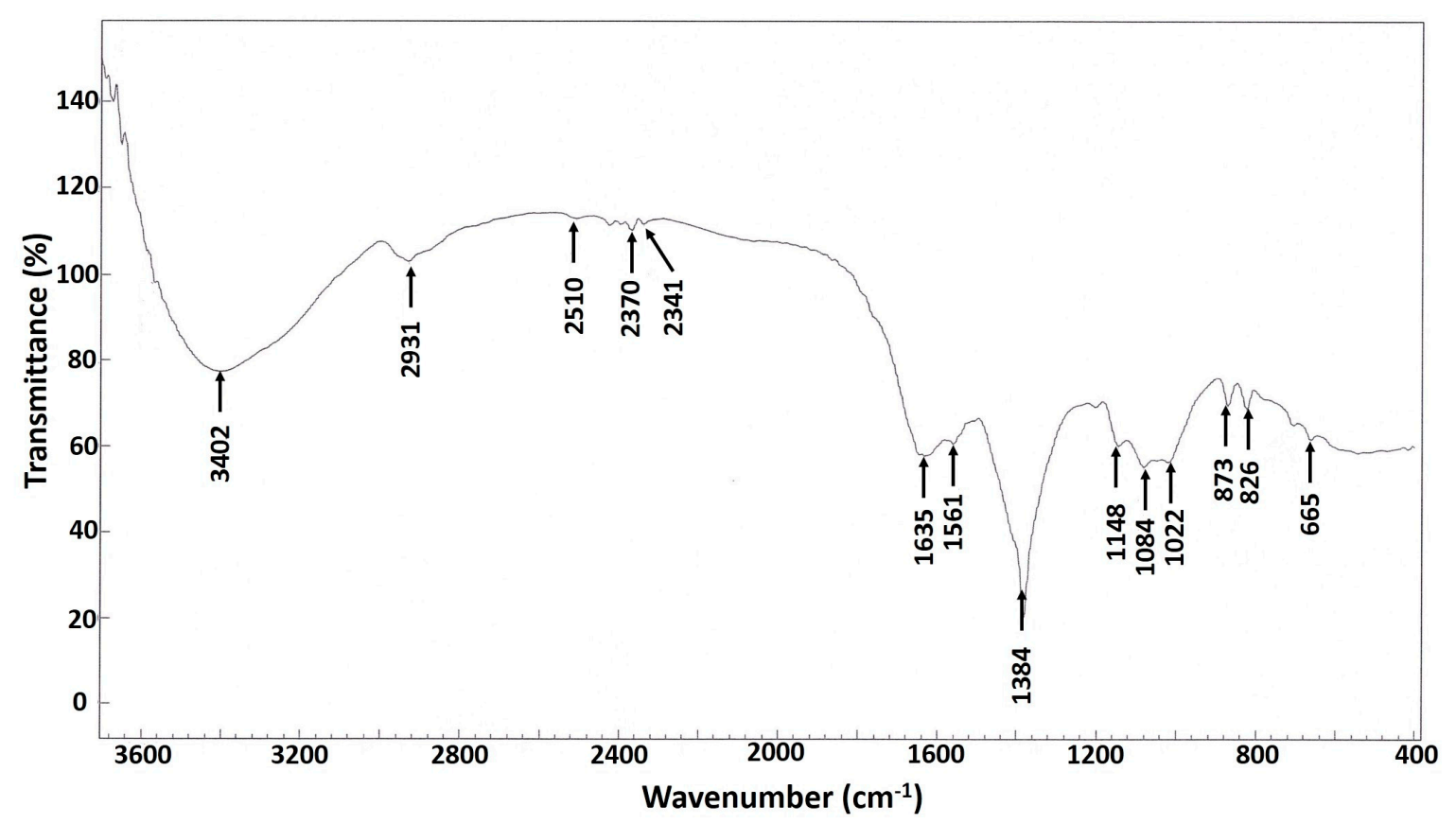

Figure 3. FT-IR spectrum of the Ag-NPs derived from endophytic S. antimycoticus L-1.

The peaks in the IR spectrum could be attributed to the presence of functional groups (e.g., C-N, $-\mathrm{OH}, \mathrm{C}=\mathrm{O}, \mathrm{C}-\mathrm{C}$ ), which may have formed due to the interactions of metabolites (e.g., proteins) with the biofabricated Ag-NPs. These results are consistent with those obtained by El-Naggar et al. [52], and Sastry et al. [53], who reported that the functional groups (or peaks) such as $\mathrm{C}=\mathrm{O}$ and $\mathrm{C}-\mathrm{C}$ arise from heterocyclic compounds, such as proteins, which act as capping agents for NPs.

\subsubsection{TEM Analysis}

The TEM images illustrate the structural qualities of the S. antimycoticus derived Ag-NPs (Figure 4A). The biogenic nano-scaled particles exhibit a spherical shape with size variation between $13 \mathrm{~nm}$ and $40 \mathrm{~nm}$ (Figure 4A), where the nanoparticles are monodispersed without any aggregation. The biofabricated nanoparticles were identical in shape and size to those in previous studies [54,55]. In agreement with our results, Hamouda et al. [56], demonstrated the synthesis of spherical monodispersed silver nanoparticles from a cyanobacterial aqueous extract, which had a dual role in both stabilizing and reducing silver nanoparticles. 

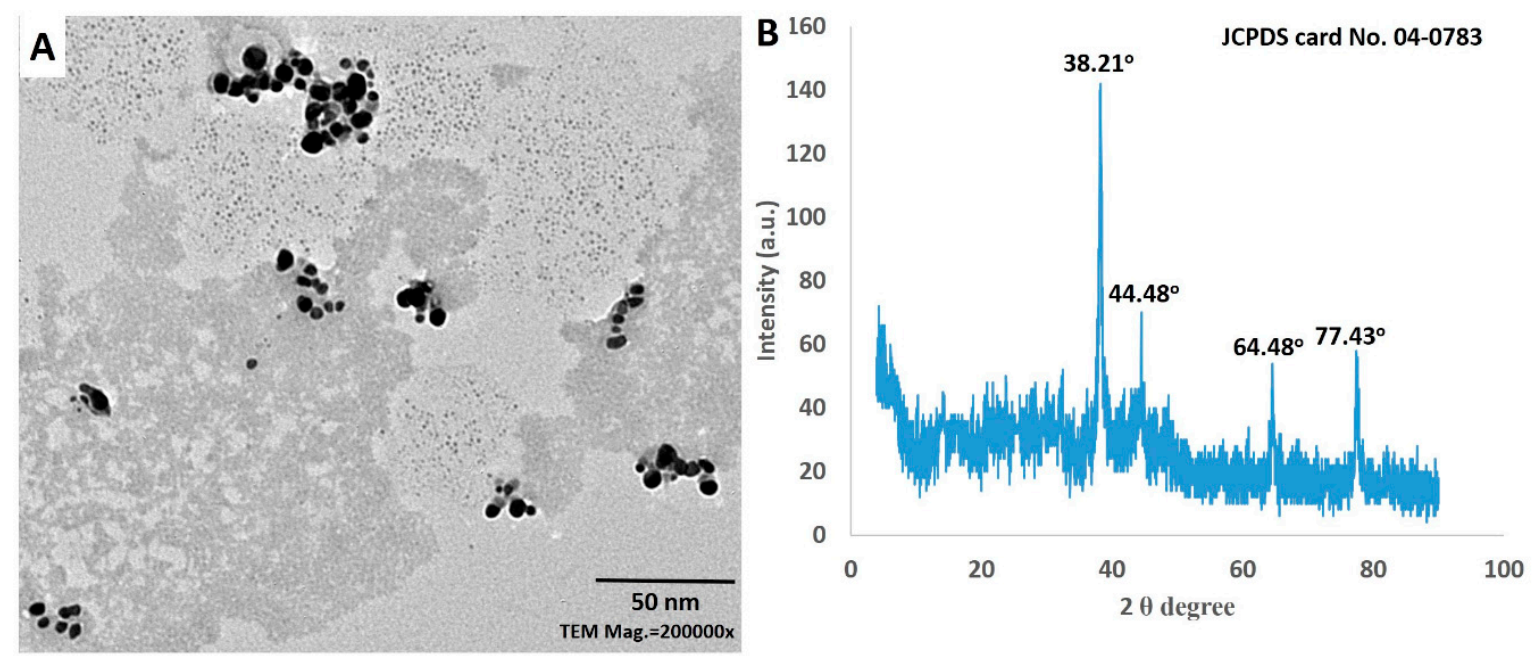

\section{C}

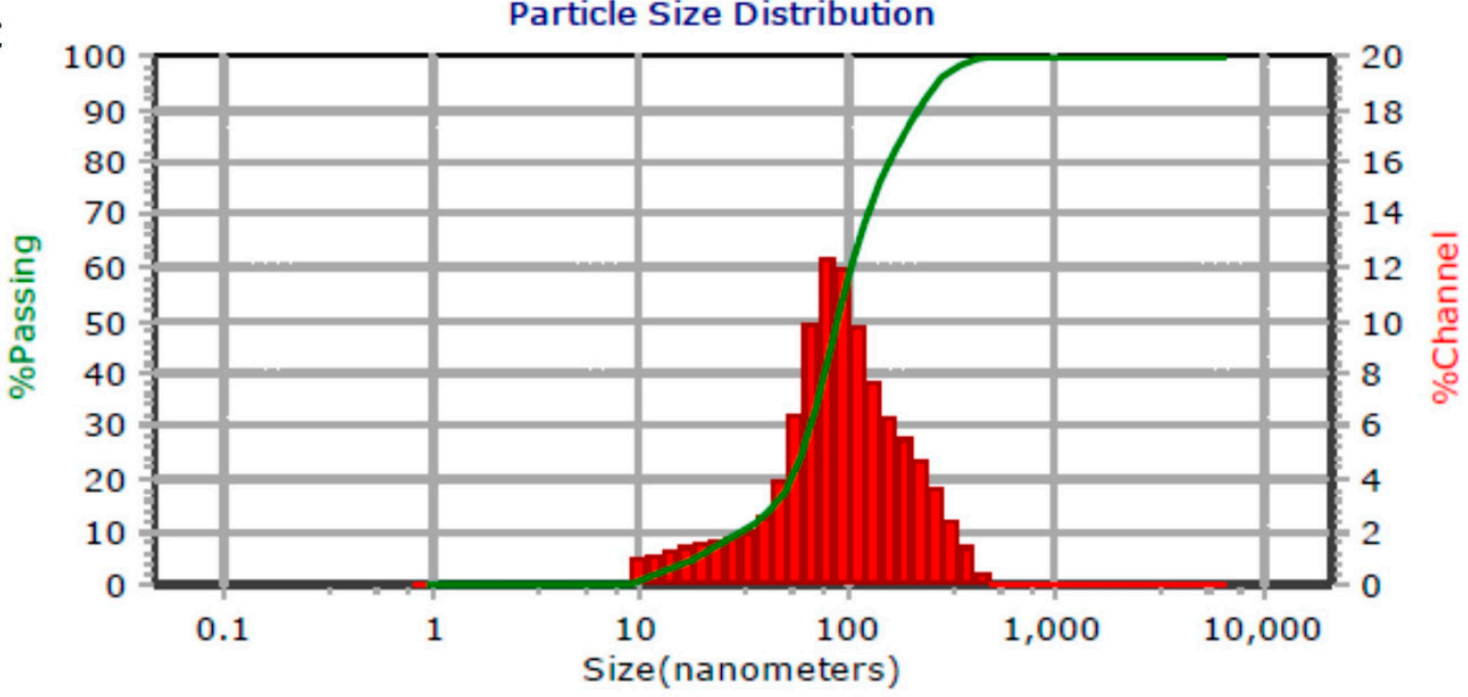

Figure 4. Characterization of Ag-NPs synthesized by Streptomyces antimycoticus L-1: (A) transmission electron microscopy (TEM) image; (B) X-ray diffraction (XRD) analysis; (C) dynamic light scattering (DLS) analysis.

\subsubsection{XRD Analysis}

The structural information of the biogenic Ag-NPs was confirmed by the XRD analysis. The XRD pattern showed the main reflection planes at the $2 \theta$ degrees of $38.21^{\circ}, 44.48^{\circ}, 64.58^{\circ}$, and $77.43^{\circ}$, corresponding to the lattice plane clusters of (111), (200), (220), and (311), respectively (Figure 4B). The XRD spectrum was compared with standard powder diffraction (JCPDS card no. 04-0783), in order to ensure that the particles in the sample were silver nanoparticles with the characteristic face-centered cubic (FCC) structure of silver crystals [57]. In this study, the plane (111) is the dominant between Ag spheres. This result was compatible with Railean-Plugaru et al., who reported that peak 111 was the dominant among Ag spheres synthesized by actinobacterial Streptacidiphilus sp. strain CGG11n [22]. The mean crystalline size of biogenic Ag-NPs was estimated by the Debye-Scherrer's equation.

Analysis of the data showed that the crystalline size of the biologically synthesized Ag-NPs was in the range of $19-35 \mathrm{~nm}$, with an average size $\sim 27 \mathrm{~nm}$. The diffractogram contained weak diffraction peaks, which could be attributed to the bio-organic molecules on the surface of the silver nanoparticles [58]. In agreement with our results, Abd-Elnaby et al. [59] reported the extracellular synthesis of silver nanoparticles from marine Streptomyces rochei MHM13 with the particle size range of $22-85 \mathrm{~nm}$. 


\subsubsection{DLS Analysis}

The size of Ag-NPs in the colloidal solution was estimated by dynamic light scattering analysis, through the reaction of light beams with the biosynthesized NPs [60]. The diameter of nanoparticles in the colloidal solution (100\%) was approximately $90.2 \mathrm{~nm}$ (Figure 4C). The size of Ag-NPs acquired from DLS analysis was bigger than those attained from TEM and XRD analyses. These results could be attributed to the size assembled from DLS depending on actinobacterial metabolites that had accumulated on the particle surface, which were responsible for reducing, capping, and stabilizing. Furthermore, the metallic core and non-homogeneous particle distributions have been correlated to bigger NPs sizes under DLS [60,61]. On the other hand, through the assessment of PDI values, DLS analysis provides an articulation about the homogeneity of NPs in colloidal solutions. The homogeneity of the NPs solution is increased or decreased if PDI value is more or less than 0.4 , while it is heterogeneous if the PDI value is $\leq 1$. The obtained data highlighted that the PDI value of the biosynthesized Ag-NPs was equal to 0.5 . Furthermore, the stability of the biogenic Ag-NPs was distinguished by zeta potential analysis $(\zeta)$ through the measurement of surface particle charge. In this study, the $\zeta$ value for Ag-NPs was recorded as $-19.2 \mathrm{mV}$, which reflects the stability of the biosynthesized NPs solution. These results are compatible with those of other UV-vis spectroscopy analyses, in which the $\zeta$ values of Ag-NPs synthesized by Streptomyces noursei H1-1 and Trichderma longibrachiatum were $-18.9 \mathrm{mV}$, and $-19.7 \mathrm{mV}$, respectively $[9,62]$.

\subsection{Antibacterial Activity of Ag-NPs}

The antibacterial performance of the biogenic silver nanoparticle suspension was evaluated against selected pathogenic bacteria using the well-diffusion assay. The investigated bio-colloidal silver offered auspicious nano-antibiotic properties, with broad-spectrum activity against both Gram-negative and Gram-positive pathogenic bacteria. Evaluation of the antibacterial activity of Ag-NPs by an agar well diffusion test has been previously carried out [63]. Silver nanoparticles at $12.5 \mathrm{ppm}$ exhibited inhibitory effects against Bacillus subtilis, Escherichia coli and Pseudomonas aeruginosa, forming inhibition zones (ZOI) of $(13.3 \pm 0.6),(9.5 \pm 0.4)$, and $(10.3 \pm 0.3) \mathrm{mm}$, respectively. It has been proven that the antibacterial activity of silver nanoparticles depends on the concentration. For example, at a Ag-NP concentration of $25 \mathrm{ppm}$, higher activities were seen against bacterial pathogens, with recorded ZOIs of (13.6 \pm 0.7$)$, $(12.5 \pm 0.4)$, and $(13 \pm 0.8) \mathrm{mm}$ corresponding to Bacillus subtilis, Escherichia coli, and Pseudomonas aeruginosa, respectively. Moreover, Staphylococcus aureus and Salmonella typhimurium showed sensitivity to bio-colloidal silver at $25 \mathrm{ppm}$, with recorded ZOIs of $(10.16 \pm 0.7)$ and $(9.5 \pm 0.4) \mathrm{mm}$, respectively. The Streptomyces-derived Ag-NPs showed enhanced antibacterial activity against all tested pathogens at $50 \mathrm{ppm}$, and $75 \mathrm{ppm}$. The maximum antibacterial activity was seen with the highest nano-silver concentration of $100 \mathrm{ppm}$, which exhibited the highest ZOIs values of $(16.33 \pm 0.5),(21.7 \pm 1.0)$, $(18.3 \pm 0.5),(20.3 \pm 1.4)$ and $(15.3 \pm 0.6) \mathrm{mm}$ for Staphylococcus aureus, Bacillus subtilis, Escherichia coli, Pseudomonas aeruginosa, and Salmonella typhimurium, respectively. Moreover, Bacillus subtilis presented the highest sensitivity to the silver nano-antibiotics, while the lowest sensitivity was assigned to Salmonella typhimurium. Bio-colloidal silver synthesized from actinomycetes have exhibited an efficient nano-antibiotics and antibacterial activities [64]. Corresponding with our investigations, the well diffusion method was used to evaluate the antibacterial properties of Streptomyces sp-induced silver nanoparticles, which displayed good antibacterial activity against Gram-negative and Gram-positive bacteria, including methicillin-resistant Staphylococcus aureus (MRSA) [65]. The antibacterial potential of the silver nanomaterials from Streptomyces parvus against various pathogens, including S. aureus, E. coli, E. faecalis, P. aeruginosa and K. pneumoniae, has been recently reported [66]. The antibacterial properties of biogenic Ag-NPs may be attributed to different mechanisms, such as charge influence of Ag-NPs. The partial dissolution of the bacterial cell membrane may be achieved due to the electrostatic attraction between the negative charge of the cell wall and the positive charge of the silver nanomaterial or by the interaction of nano-scaled silver with phosphorylated or sulfur proteins of the bacterial cell wall, causing the destabilization and depolarization of bacteria membrane to lose its integrity and 
leakage of $\mathrm{H}^{+}$[67]. Anther mechanism of biological toxicity of Ag-NPs could be attributed to the release of $\mathrm{Ag}^{+}$through oxidation process. In this mechanism, $\mathrm{Ag}$-NPs act as a carrier for $\mathrm{Ag}^{+}$, once liberated, $\mathrm{Ag}^{+}$reacts with phosphate, thiol group of cysteine amino acids, glutamine amino acid, and carboxyl group, leading to bacterial death $[68,69]$. Moreover, the biocidal effect of Ag-NPs could be attributed to elevated ROS as a result of $\mathrm{Ag}^{+}$release, which destroys cellular respiration enzymes and the ultimate result is cell death [46]. Recently, Alsharif et al. [9] reported the extracellular synthesis of Ag-NPs by Streptomyces noursei H1-1 and declared the potential antibacterial activity of these nanoparticles in low concentrations ( $25 \mathrm{ppm}$ and $50 \mathrm{ppm}$ ) against the selected pathogens S. typhimurium, P. aeruginosa, E. coli, B. subtilis, and S. aureus. In the same context, Wypij et al. [70] reported the biogenic synthesis of Ag-NPs from Streptomyces xinghaiensis OF1 with efficient nano-antibiotic properties against B. subtilis, S. aureus, E. coli, and P. aeruginosa. Dong et al. [25] announced the bacteriostatic action of biosynthetic Ag-NPs against Vibrio Natriegens; additionally, they indicated an inverse relationship between the size of nanoparticles and their antibacterial activity. Our results revealed that the Streptomyces-derived Ag-NPs were active at low concentration ( $25 \mathrm{ppm}$ ) against all selected pathogens. The MIC values of biosynthesized Ag-NPs against S. aureus, B. subtilis, E. coli, P. aeruginosa, and S. typhimurium were $25.0 \mathrm{ppm}, 12.5 \mathrm{ppm}, 12.5 \mathrm{ppm}, 12.5 \mathrm{ppm}$ and $25.0 \mathrm{ppm}$, respectively, with ZOIs of (10.16 \pm 0.7), $(13.3 \pm 0.6),(10.3 \pm 0.3),(9.5 \pm 0.4)$ and $(9.5 \pm 0.4) \mathrm{mm}$ as shown in Figure 5. Hence, Ag-NPs have been shown to manifest powerful antibacterial activities, which might be clinically useful for controlling various bacterial infections.

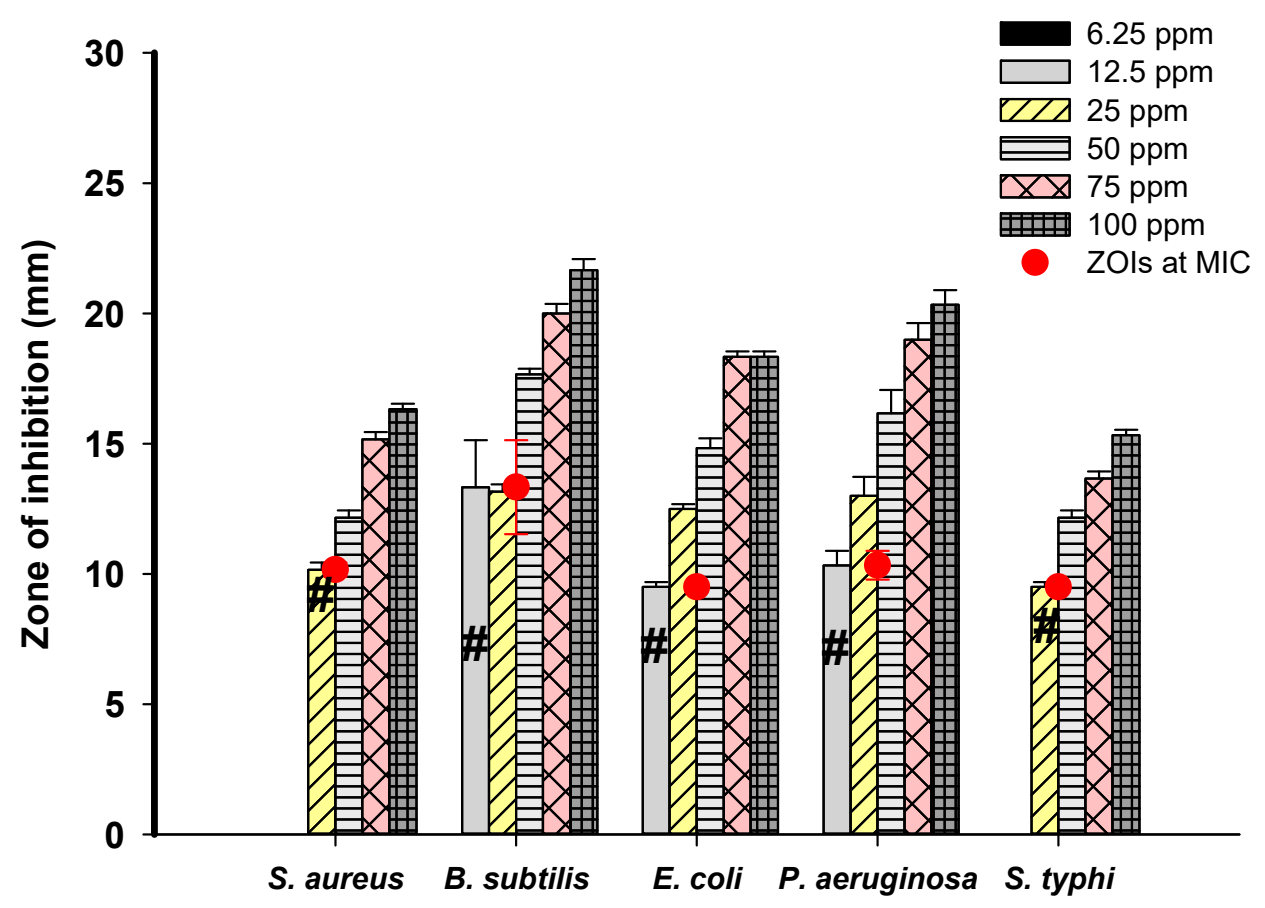

Figure 5. Antibacterial activities and minimum inhibitory concentrations (MICs) for Ag-NPs synthesized by S. antimycoticus L-1 against pathogenic S. aureus, B. subtilis, P. aeruginosa, E. coli, and S. typhimurium. \# indicates MIC value.

\subsection{Cytotoxic Activity of Ag-NPs Against Cancer and Normal Cells}

Silver nanoparticles play a paramount role in nano-medicine, with potential for use as antibacterial or anticancer agents [71,72]. Interestingly, biologically derived nanoparticles are more effective in biomedical applications, as compared to those manufactured by physical or chemical procedures [73,74]. Diverse anticancer drugs have been developed using nanotechnology; for example, Myocet ${ }^{\mathrm{TM}}$ (Perrigo, Dublin, Ireland), Abraxane ${ }^{\circledR}$ (Celgene, Summit, NJ, USA) and Doxil ${ }^{\circledR}$ (Johnson and Johnson, New Brunswick, NJ, USA) have been recently approved by the Food and Drug Administration (FDA) for clinical 
applications [75]. Accordingly, the current study was designed to assess the potential anticancer activity of the biosynthesized Ag-NPs. Therefore, an MTT experiment was performed to estimate the cytotoxic effect of Ag-NPs synthesized by S. antimycoticus against the cancerous Caco-2 (human colon cancer) and normal Vero (kidney of African green monkey) cell lines. MTT is an accurate colorimetric method that is commonly used to evaluate cellular toxicity, as well as cell proliferation and viability. The microscopic investigation of cell lines exposed to Ag-NPs exhibited the cytotoxicity of nanoparticles against mammalian cells, which resulted in the loss of the characteristic monolayer of these epithelial cells. Moreover, we found that the cytotoxic properties of Ag-NPs were dose-dependent. The reduced viability of cancerous caco- 2 cell lines could be attributed to the apoptotic effect induced by the biogenic silver nanoparticles. However, other mechanisms for cytotoxicity of Ag-NPs have been studied, such as modifying the mitochondrial membrane potential, DNA fragmentation, leakage of lactate dehydrogenase (LDH), activation of apoptotic caspases, ROS generation and nuclear fragmentation [76]. In agreement with our results, the Streptomyces noursei H1-1-based Ag-NPs manifested a functional dose-dependent cytotoxic effect against cancerous cell lines, where very low concentrations $(5.6 \pm 3.0 \mu \mathrm{g} / \mathrm{mL}$ ) of Ag-NPs inhibited $50 \%$ of caco-2 (cancer cell line); while the normal Vero cell line, when exposed to $(511.7 \pm 68.5) \mu \mathrm{g} / \mathrm{mL}$ of bio-silver nanoparticles, halved their cell viable cell count [9]. Recently, Liao et al. [77] have reported the dose, time, and size dependency of the Ag-NPs mediated cytotoxicity, mainly for particles smaller than $10 \mathrm{~nm}$. According to our results, the nano-processed cell lines lost their adherent ability, as evidenced by the complete or partial breakdown of the monolayer integrity, as well as shrinking, floating, and cells becoming granular and round. Similar morphological modifications were obtained after incubating human cancer cells (Caco-2) and normal cell lines (WI 38) with biogenic Selenium nanomaterials, which led to modified cell shape, rounding, granulation, shrinking, and the loss of monolayer integrity in cloned cell [78]. The cytotoxic abilities $\left(\mathrm{IC}_{50}\right)$ of the biogenic Ag-NPs (values for $50 \%$ inhibition of cell viability) were calculated graphically (Figure 6). The toxicity of biogenic Ag-NPs against human colon carcinoma cell line (HCT-116) and breast cancer cell line (MCF-7) has been determined, recording the $\mathrm{IC}_{50}$ values of $5.4 \mu \mathrm{g} / \mathrm{mL}$ and $6.1 \mu \mathrm{g} / \mathrm{mL}$, respectively [56]. In the current study, the normal Vero cells recorded a higher $\mathrm{IC}_{50}$ value $(274.8 \pm 12.8 \mathrm{ppm})$ than the value for the cancerous Caco-2 cell line ( $\left.5.74 \pm 0.2 \mathrm{ppm}\right)$. The lowered effect of the Streptomyces-derived Ag-NPs on the Vero cells, compared to its potent impact on the Caco-2 tumor cell line, revealed its selective activity toward the carcinoma cell line and, thus, its potential for clinical use as a safe therapeutic agent. According to data of the antibacterial activity and in-vitro cytotoxicity, we can select a safe dose to apply on cotton fabrics.

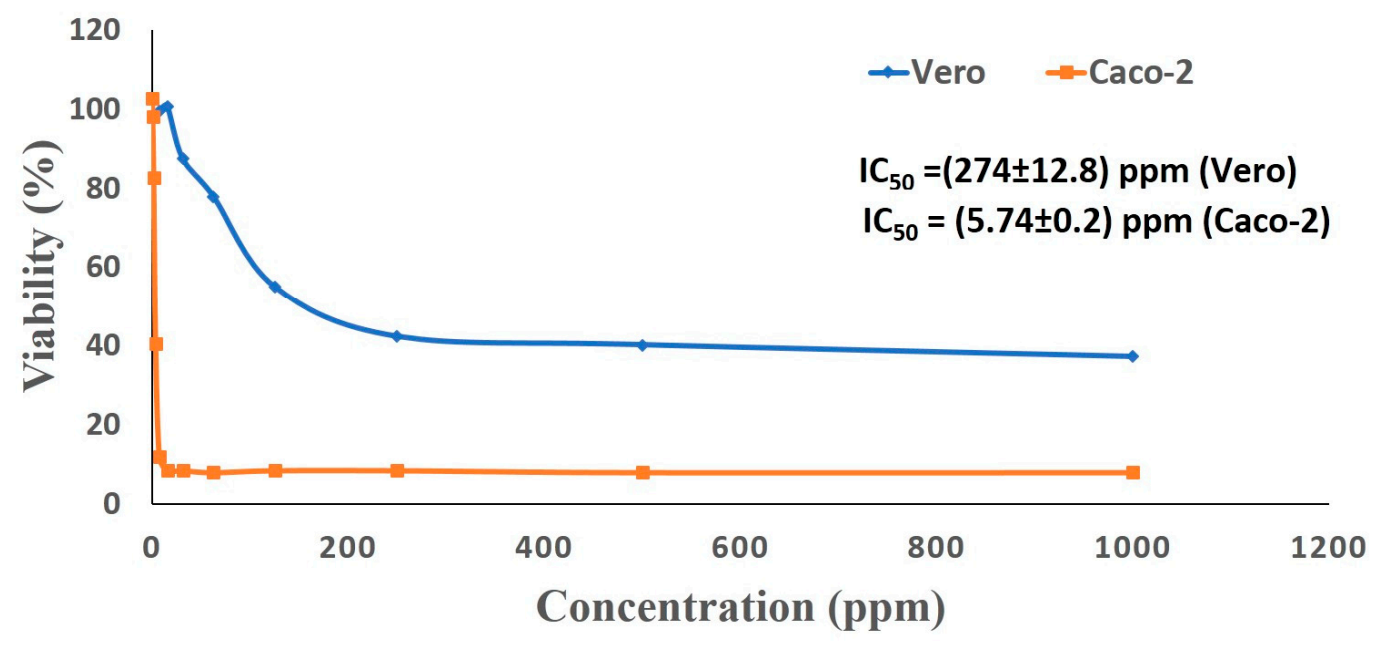

Figure 6. Cytotoxic activity of Ag-NPs derived from S. antimycoticus L-1 against Vero and Caco-2 cell lines. 


\subsection{Application of Ag-NPs for Medical Fabrics}

\subsubsection{Loading Biogenic Ag-NPs onto Cotton Textile}

Cotton fabric pieces were washed with warm water and subjected to a simple pad technique, in order to be loaded with a solution of the biologically manufactured Ag-NPs (100 ppm); this concentration was deemed safe for the normal cell line (based on our investigations of cytotoxicity). The color of treated fabrics by a safe Ag-NPs dose tends to be a pale yellow. Washing and flooding fabrics with water before nano-finishing composes a negative charge on the surface of the textile, such that the positively charged Ag-NPs would be electrostatically attracted to that negative charge on the fabric surface [79]. The surface morphology of textile samples was then examined by SEM. The blank fabric showed a refined overlapping fibrous frame with a soft surface, without any contaminants or depositions (Figure 7A). As for the treated fabric, although it seemed to retain its structure, its surface was covered with Ag-NPs that were incorporated into the tissue fibers and evenly dispersed across the surface of the textile (Figure 7B,C). In this respect, Xing et al. [80] reported the effective deposition of nano-sized silver, which was homogeneously distributed on the textile surface. In the present study, our characterization of the Streptomyces-derived Ag-NPs revealed their small size (13-40 nm), which could support their adhesion to the fabric surface, as it is expected that smaller particles can penetrate deeply into the fabric and tightly adhere to the textile fibers. Furthermore, EDX spectroscopy determined the chemical elements of the nano-finished fabrics, declaring peaks corresponding to $\mathrm{C}$ and $\mathrm{O}$, as well as an incoming peak monitored around $3 \mathrm{keV}$, which could be attributed to the nano-scale silver particles. Silver nanoparticles represented about $2 \%$ of the total elements on the modified fabrics surface and approximately $0.38 \%$ of the weight of the surface elements (Figure 7D). Accordingly, the SEM/EDX results confirmed the existence of Ag-NPs attached to the textile surface. In line with the current study, Othman et al. [81] reported the efficient application of bio-fabricated Ag-NPs for functionalizing nano-finished fabrics with antimicrobial properties; their EDX spectra showed a strong peak around $3.0 \mathrm{keV}$, thus demonstrating the deposition of nano-sized silver on the textile surface. Our results showed that the bio-silver nanoparticles effectively integrated into the surface of the treated fabrics and formed a reinforced surface layer; thus, they can be used as finishing materials for the multifunctional fabrics.

\subsubsection{Antibacterial Activity of Nano-Coated Fabrics}

Fabrics in contact with the human body provide a moist and warm climate for microorganisms; as such, sweaty clothes are considered a perfect environment for bacterial outgrowth and propagation $[82,83]$. Therefore, the development of Ag-based antimicrobial fabrics for the treatment of clinical bandages and clothing is a promising solution for biomedical applications. Moreover, nano-finished textiles possess water- and/or oil-repellent properties [84], thus contributing to prevention of microbial growth on the processed fabrics.

The antibacterial activities of nano-finished fabrics have been qualitatively evaluated against selected pathogenic bacteria by investigating zones of inhibition. Our investigations revealed that blank fabric pieces had no antibacterial effects either before or after laundering. On the contrary, the Ag-based biological fabrics exhibited significant antibacterial activity. Although the biogenic colloidal silver was applied at a low concentration, its regular distribution across the fabric surface provided broad-spectrum activity. The silver-coated fabrics presented the highest activity against B. subtilis, recording an inhibition zone of $(2.7 \pm 0.3) \mathrm{mm}$, while the minimum inhibition zone was registered for $P$. aeruginosa $(1.3 \pm 0.01 \mathrm{~mm})$. Furthermore, the modified textile displayed significant antibacterial properties versus E. coli and S. aureus, recording growth inhibition zones of $(2.1 \pm 0.2)$, $(1.8 \pm 0.1) \mathrm{mm}$, respectively. Washing fastness is a key factor for nano-finished fabrics to remain applicable; it has been noticed that the efficacy of the Ag- fabrics against tested bacteria reduced after washing. However, our results demonstrated the durability of the proposed silver-based fabrics, which retained their biocidal potential after even 10 repetitive washing cycles (Table 1). Nevertheless, Ag-NPs 
could be abraded from the fabric by the mechanistic vibration and raised temperature during laundry procedures [78]. Therefore, it is expected that the nano-finished fabrics will lose their antibacterial activity after repeated washing. In line with our results, Othman et al. [81] used fungus-derived colloidal silver to functionalize fabrics and reported the activity of the processed fabric against Candida albicans, Bacillus mycoides, and Escherichia coli, as well as the durability of the nano-finished fabrics and their stability after five washing cycles. Moreover, our data were compatible with those of El-Naggar et al. [52], who reported the efficacy of cotton fabrics loaded with Ag-NPs synthesized by Streptomyces sp. strain SSHH-1E against pathogenic Gram-positive, Gram-negative, and yeast species.

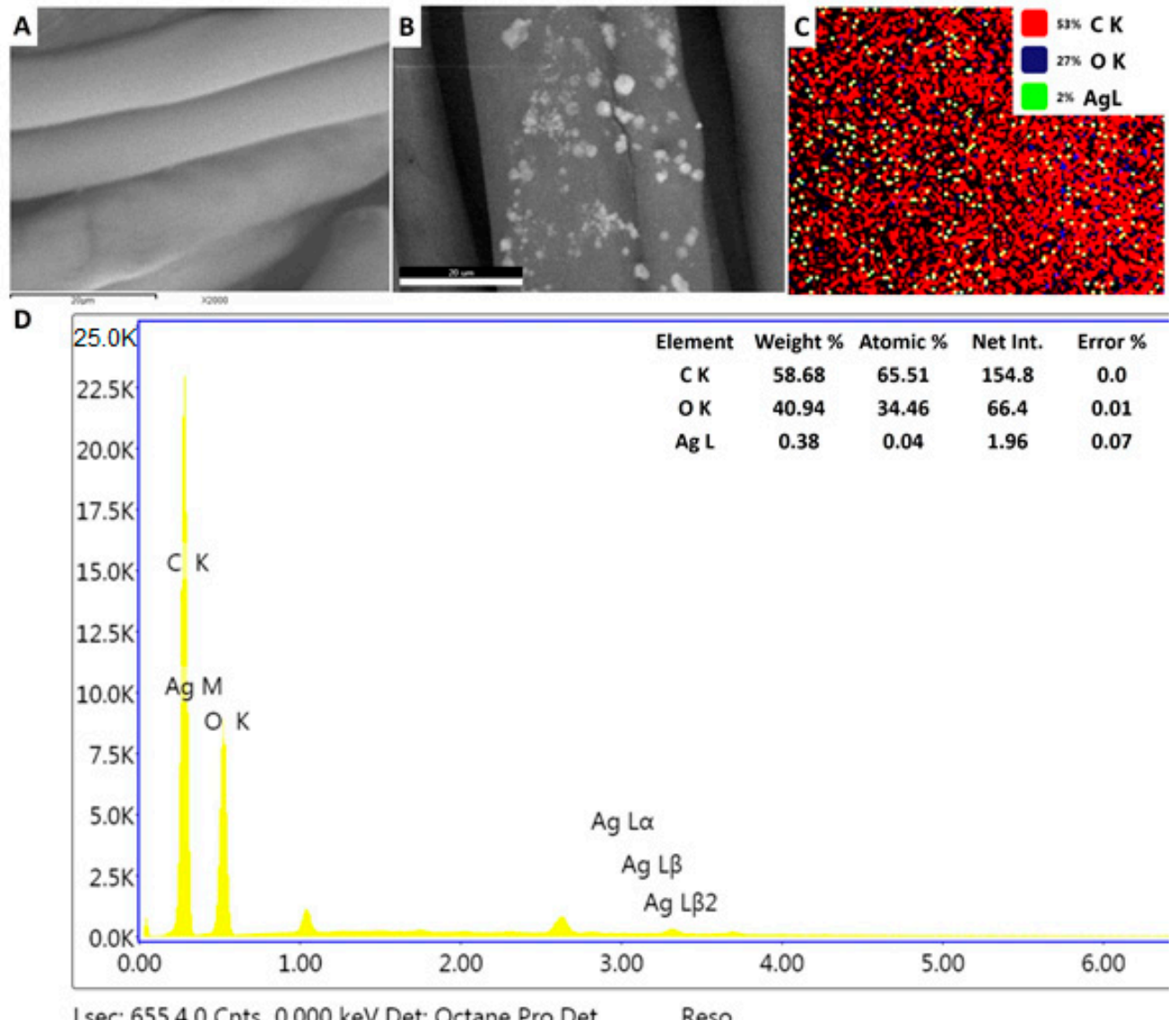

Figure 7. Scanning electron microscopy results for cotton fabrics; (A) cotton fabric without any treatment, and showing smooth surface; (B) cotton fabrics treated with Ag-NPs (100 ppm), showing the deposited NPs on the cotton surface; (C) mapping picture of treated fabrics with Ag-NPs, showing qualitative elemental analysis; (D) EDX of the treated sample with elemental analysis of the Ag-NPs contents.

Table 1. Effect of repeated washing on the antibacterial properties of silver nanoparticle-finished fabrics by qualitative assessment method.

\begin{tabular}{ccccc}
\hline \multirow{2}{*}{$\begin{array}{c}\text { Number of } \\
\text { Washing Cycles }\end{array}$} & \multicolumn{4}{c}{ Clear Zone (mm) } \\
\cline { 2 - 5 } & S. aureus & B. subtilis & P. aeruginosa & E. coli \\
\hline Before & $1.8 \pm 0.1^{\mathrm{a}}$ & $2.7 \pm 0.3^{\mathrm{a}}$ & $1.3 \pm 0.01^{\mathrm{a}}$ & $2.1 \pm 0.18^{\mathrm{a}}$ \\
\hline After 5 cycles & $0.9 \pm 0.1^{\mathrm{b}}$ & $1.9 \pm 0.1^{\mathrm{b}}$ & $0.9 \pm 0.03^{\mathrm{b}}$ & $1.8 \pm 0.07^{\mathrm{b}}$ \\
\hline After 10 cycles & $0.7^{\mathrm{b}} \pm 0.1^{\mathrm{c}}$ & $1.5 \pm 0.2^{\mathrm{c}}$ & $0.6 \pm 0.7^{\mathrm{c}}$ & $0.9 \pm 0.05^{\mathrm{c}}$ \\
\hline
\end{tabular}

Different letters between columns denote significantly different $(p \leq 0.05)$ mean values, as determined by the Honestly Significant Difference (LSD) test. 


\section{Conclusions}

In this study, healthy leaves of the medicinal plant Mentha longifolia L. were collected from Rihibat Nada, Saint Katherine, South Sinai, Egypt, and used for the isolation of endophytic actinobacteria, which was identified as Streptomyces antimycoticus L-1 based on $16 S$ rRNA sequencing. The S. antimycoticus L-1 strain was used as a biocatalyst for reducing, capping, and stabilizing Ag-NPs. A color change from colorless to yellowish-brown was the first monitored for the green synthesis of Ag-NPs using metabolites involving the biomass filtrate of endophytic S. antimycoticus L-1. Physico-chemical Ag-NPs characterizations were achieved by UV-vis spectroscopy, FT-IR, TEM, XRD, DLS and zeta potential analyses. The data confirmed the preparation of crystalline, spherical Ag-NPs with an average size of 13-40 nm at maximum SPR $415 \mathrm{~nm}$, which remained stable for a long time. In addition, our data demonstrated the high stability and homogeneity of Ag-NPs, with a negative surface charge of $-19.2 \mathrm{mV}$ and polydispersity index (PDI) equal to 0.5. Analysis of the biological activities of the green-synthesized Ag-NPs revealed their efficacy as bactericidal agents against pathogenic Gram-positive and Gram-negative bacteria, as well as their in-vitro cytotoxicity against a cancerous cell line. Furthermore, cotton fabrics treated with a safe Ag-NPs dose (100 ppm) acquired new functional properties, including self-cleaning against pathogenic bacteria.

Author Contributions: Conceptualization, A.F., S.S.S., S.E.-D.H., and T.I.S.; methodology, A.F., S.S.S., S.E.-D.H., A.E., M.A., T.I.S., G.N., A.M.E., and E.F.E.-B.; software, A.M.E., A.F., S.E.-D.H., S.S.S., G.N., E.F.E.-B., and T.I.S.; validation, A.F., S.E.-D.H., S.S.S., A.M.E., E.F.E.-B., G.N., and T.I.S.; formal analysis, A.M.E., A.F., S.E.-D.H., S.S.S., E.F.E.-B. and T.I.S.; investigation, A.F., A.E., M.A., S.E.-D.H., S.S.S., A.M.E., E.F.E.-B. and T.I.S.; resources, A.M.E., A.E., M.M.A., A.F., S.E.-D.H., S.S.S., E.F.E.-B., M.A and T.I.S.; data curation, A.M.E., A.F., S.E.-D.H., S.S.S., G.N., E.F.E.-B. and T.I.S.; writing-original draft preparation, A.M.E., A.F., M.A, S.E.-D.H., S.S.S., G.N., E.F.E.-B. and T.I.S.; writing-review and editing, A.M.E., A.F., S.E.-D.H., S.S.S., A.E., M.M.A., G.N., E.F.E.-B., and T.I.S., Funding G.N. and A.E. All authors have read and agreed to the published version of the manuscript.

Funding: This research received no external funding.

Conflicts of Interest: The authors declare no conflict of interest.

\section{References}

1. Fahimirad, S.; Ajalloueian, F.; Ghorbanpour, M. Synthesis and therapeutic potential of silver nanomaterials derived from plant extracts. Ecotoxicol. Environ. Saf. 2019, 168, 260-278. [CrossRef]

2. Hassan, S.E.L.D.; Salem, S.S.; Fouda, A.; Awad, M.A.; El-Gamal, M.S.; Abdo, A.M. New approach for antimicrobial activity and bio-control of various pathogens by biosynthesized copper nanoparticles using endophytic actinomycetes. J. Radiat. Res. Appl. Sci. 2018, 11, 262-270. [CrossRef]

3. Fouda, A.; Abdel-Maksoud, G.; Abdel-Rahman, M.A.; Salem, S.S.; Hassan, S.E.D.; El-Sadany, M.A.H. Eco-friendly approach utilizing green synthesized nanoparticles for paper conservation against microbes involved in biodeterioration of archaeological manuscript. Int. Biodeterior Biodegrad. 2019, 142, 160-169. [CrossRef]

4. Abdel-Azeem, A.; Nada, A.; O’Donovan, A.; Kumar Thakur, V.; Elkelish, A. Mycogenic Silver Nanoparticles from Endophytic Trichoderma atroviride with Antimicrobial Activity. J. Renew. Mater 2020, 8, 171-185. [CrossRef]

5. Soliman, M.; Qari, S.H.; Abu-Elsaoud, A.; El-Esawi, M.; Alhaithloul, H.; Elkelish, A. Rapid green synthesis of silver nanoparticles from blue gum augment growth and performance of maize, fenugreek, and onion by modulating plants cellular antioxidant machinery and genes expression. Acta Physiol. Plant 2020, 42, 148. [CrossRef]

6. $\quad$ Elfeky, A.S.; Salem, S.S.; Elzaref, A.S.; Owda, M.E.; Eladawy, H.A.; Saeed, A.M.; Awad, M.A.; Abou-Zeid, R.E.; Fouda, A. Multifunctional cellulose nanocrystal /metal oxide hybrid, photo-degradation, antibacterial and larvicidal activities. Carbohydr. Polym. 2020, 230. [CrossRef]

7. Salem, S.S.; Fouda, A. Green Synthesis of Metallic Nanoparticles and Their Prospective Biotechnological Applications: An Overview. Biol. Trace Elem. Res. 2020. [CrossRef] 
8. Shaheen, T.I.; Salem, S.S.; Zaghloul, S. A New Facile Strategy for Multifunctional Textiles Development through in Situ Deposition of $\mathrm{SiO}_{2} / \mathrm{TiO}_{2}$ Nanosols Hybrid. Ind. Eng. Chem. Res. 2019, 58, 20203-20212. [CrossRef]

9. Alsharif, S.M.; Salem, S.S.; Abdel-Rahman, M.A.; Fouda, A.; Eid, A.M.; El-Din Hassan, S.; Awad, M.A.; Mohamed, A.A. Multifunctional properties of spherical silver nanoparticles fabricated by different microbial taxa. Heliyon 2020, 6. [CrossRef]

10. Mohamed, A.A.; Abu-Elghait, M.; Ahmed, N.E.; Salem, S.S. Eco-friendly Mycogenic Synthesis of ZnO and $\mathrm{CuO}$ Nanoparticles for In Vitro Antibacterial, Antibiofilm, and Antifungal Applications. Biol. Trace Elem. Res. 2020. [CrossRef]

11. Fouda, A.; Hassan, S.E.-D.; Salem, S.S.; Shaheen, T.I. In-Vitro cytotoxicity, antibacterial, and UV protection properties of the biosynthesized Zinc oxide nanoparticles for medical textile applications. Microb. Pathog. 2018, 125, 252-261. [CrossRef] [PubMed]

12. Mohamed, A.A.; Fouda, A.; Abdel-Rahman, M.A.; Hassan, S.E.-D.; El-Gamal, M.S.; Salem, S.S.; Shaheen, T.I. Fungal strain impacts the shape, bioactivity and multifunctional properties of green synthesized zinc oxide nanoparticles. Biocatal. Agric. Biotechnol. 1011, 03. [CrossRef]

13. Mukherjee, S.; Chowdhury, D.; Kotcherlakota, R.; Patra, S. Potential theranostics application of bio-synthesized silver nanoparticles (4-in-1 system). Theranostics 2014, 4, 316-335. [CrossRef]

14. Fouda, A.; Abdel-Maksoud, G.; Abdel-Rahman, M.A.; Eid, A.M.; Barghoth, M.G.; El-Sadany, M.A.H. Monitoring the effect of biosynthesized nanoparticles against biodeterioration of cellulose-based materials by Aspergillus niger. Cellulose 2019, 26, 6583-6597. [CrossRef]

15. Aref, M.S.; Salem, S.S. Bio-callus synthesis of silver nanoparticles, characterization, and antibacterial activities via Cinnamomum camphora callus culture. Biocatal. Agric. Biotechnol. 2020, 101689. [CrossRef]

16. Simončič, B.; Klemenčič, D. Preparation and performance of silver as an antimicrobial agent for textiles: A review. Text. Res. J. 2016, 86, 210-223. [CrossRef]

17. Erem, A.D.; Ozcan, G.; Skrifvars, M.; Cakmak, M. In vitro assesment of antimicrobial activity and characteristics of polyamide 6/silver nanocomposite fibers. Fibers Polym. 2013, 14, 1415-1421. [CrossRef]

18. Xue, C.-H.; Chen, J.; Yin, W.; Jia, S.-T.; Ma, J.-Z. Superhydrophobic conductive textiles with antibacterial property by coating fibers with silver nanoparticles. Appl. Surf. Sci. 2012, 258, 2468-2472. [CrossRef]

19. ALKahtani, M.D.F.; Fouda, A.; Attia, K.A.; Al-Otaibi, F.; Eid, A.M.; Ewais, E.E-D.; Hijri, M.; St-Arnaud, M.; Hassan, S.E-D.; Khan, N.; et al. Isolation and Characterization of Plant Growth Promoting Endophytic Bacteria from Desert Plants and Their Application as Bioinoculants for Sustainable Agriculture. Agronomy 2020, 10, 1325. [CrossRef]

20. Hassan, S.E.-D.; Fouda, A.; Radwan, A.A.; Salem, S.S.; Barghoth, M.G.; Awad, M.A.; Abdo, A.M.; El-Gamal, M.S. Endophytic actinomycetes Streptomyces spp mediated biosynthesis of copper oxide nanoparticles as a promising tool for biotechnological applications. JBIC J. Biol. Inorg. Chem. 2019, 24, 377-393. [CrossRef]

21. Buszewski, B.; Railean-Plugaru, V.; Pomastowski, P.; Rafińska, K.; Szultka-Mlynska, M.; Golinska, P.; Wypij, M.; Laskowski, D.; Dahm, H. Antimicrobial activity of biosilver nanoparticles produced by a novel Streptacidiphilus durhamensis strain. J. Microbiol. Immunol. Infect. 2016, 51, 45-54. [CrossRef] [PubMed]

22. Railean-Plugaru, V.; Pomastowski, P.; Wypij, M.; Szultka-Mlynska, M.; Rafinska, K.; Golinska, P.; Dahm, H.; Buszewski, B. Study of silver nanoparticles synthesized by acidophilic strain of Actinobacteria isolated from the of Picea sitchensis forest soil. J. Appl. Microbiol. 2016, 120, 1250-1263. [CrossRef] [PubMed]

23. Fouda, A.; Hassan, S.E.D.; Abdo, A.M.; El-Gamal, M.S. Antimicrobial, Antioxidant and Larvicidal Activities of Spherical Silver Nanoparticles Synthesized by Endophytic Streptomyces spp. Biol. Trace Elem. Res. 2020, 195, 707-724. [CrossRef] [PubMed]

24. Arya, G.; Sharma, N.; Mankamna, R.; Nimesh, S. Antimicrobial Silver Nanoparticles: Future of Nanomaterials. In Microbial Nanobionics: Basic Research and Applications; Prasad, R., Ed.; Springer International Publishing: Basel, Switzerland, 2019; Volume 2, pp. 89-119. [CrossRef]

25. Dong, Y.; Zhu, H.; Shen, Y.; Zhang, W.; Zhang, L. Antibacterial activity of silver nanoparticles of different particle size against Vibrio natriegens. PLoS ONE 2019, 14, e0222322. [CrossRef] 
26. Ratan, Z.A.; Haidere, M.F.; Nurunnabi, M.; Shahriar, S.M.; Ahammad, A.J.S.; Shim, Y.Y.; Reaney, M.J.T.; Cho, J.Y. Green Chemistry Synthesis of Silver Nanoparticles and Their Potential Anticancer Effects. Cancers 2020, 12, 855. [CrossRef]

27. Fouda, A.H.; Hassan, S.E.-D.; Eid, A.M.; Ewais, E.E.-D. Biotechnological applications of fungal endophytes associated with medicinal plant Asclepias sinaica (Bioss.). Ann. Agric. Sci. 2015, 60, 95-104. [CrossRef]

28. Mitra, A.; Santra, S.C.; Mukherjee, J. Distribution of actinomycetes, their antagonistic behaviour and the physico-chemical characteristics of the world's largest tidal mangrove forest. Appl. Microbiol. Biotechnol. 2008, 80, 685-695. [CrossRef]

29. Lane, D. 16S/23S rRNA sequencing. In Nucleic Acid Tech. Bact. Syst.; Stackebrandt, E., Goodfellow, M., Eds.; John Wiley and Sons: New York, NY, USA, 1991; pp. 115-175.

30. Thompson, J.D.; Gibson, T.J.; Plewniak, F.; Jeanmougin, F.; Higgins, D.G. The CLUSTAL_X windows interface: Flexible strategies for multiple sequence alignment aided by quality analysis tools. Nucleic Acids Res. 1997, 25, 4876-4882. [CrossRef]

31. Kimura, M. A simple method for estimating evolutionary rates of base substitutions through comparative studies of nucleotide sequences. J. Mol. Evol. 1980, 16, 111-120. [CrossRef]

32. Saitou, N.; Nei, M. The neighbor-joining method: A new method for reconstructing phylogenetic trees. Mol. Biol. Evol. 1987, 4, 406-425.

33. Selvakumar, P.; Viveka, S.; Prakash, S.; Jasminebeaula, S.; Uloganathan, R. Antimicrobial activity of extracellularly synthesized silver nanoparticles from marine derived Streptomyces rochei. Int. J. Pharm. Biol. Sci. 2012, 3, 188-197.

34. Soliman, A.M.; Abdel-Latif, W.; Shehata, I.H.; Fouda, A.; Abdo, A.M.; Ahmed, Y.M. Green approach to overcome the resistance pattern of Candida spp. using biosynthesized silver nanoparticles fabricated by Penicillium chrysogenum F9. Biol. Trace Elem. Res. 2020, 1-12. [CrossRef]

35. Valgas, C.; Souza, S.M.d.; Smânia, E.F.; Smânia, A., Jr. Screening methods to determine antibacterial activity of natural products. Braz. J. Microbiol. 2007, 38, 369-380. [CrossRef]

36. Philip, S.; Kundu, G.C. Osteopontin induces nuclear factor $\kappa B$-mediated promatrix metalloproteinase-2 activation through $\mathrm{I} \kappa \mathrm{B} \alpha / \mathrm{IKK}$ signaling pathways, and curcumin (diferulolylmethane) down-regulates these pathways. J. Biol. Chem. 2003, 278, 14487-14497. [CrossRef]

37. Gupta, A.; Singh, D.; Singh, S.K.; Singh, V.K.; Singh, A.V.; Kumar, A. Role of actinomycetes in bioactive and nanoparticle synthesis. In Role of Plant Growth Promoting Microorganisms in Sustainable Agriculture and Nanotechnology; Elsevier: Amsterdam, The Netherlands, 2019; pp. 163-182.

38. EL-Moslamy, S.H. Bioprocessing strategies for cost-effective large-scale biogenic synthesis of nano-MgO from endophytic Streptomyces coelicolor strain E72 as an anti-multidrug-resistant pathogens agent. Sci. Rep. 2018, 8, 1-22. [CrossRef] [PubMed]

39. Taha, Z.K.; Hawar, S.N.; Sulaiman, G.M. Extracellular biosynthesis of silver nanoparticles from Penicillium italicum and its antioxidant, antimicrobial and cytotoxicity activities. Biotechnol. Lett. 2019, 41, 899-914. [CrossRef]

40. Nasrollahzadeh, M.; Sajjadi, M.; Tahsili, M.R.; Shokouhimehr, M.; Varma, R.S. Synthesis of 1-substituted $1 \mathrm{H}-1$, 2, 3, 4-tetrazoles using biosynthesized Ag/sodium borosilicate nanocomposite. ACS Omega 2019, 4, 8985-9000. [CrossRef]

41. Khodadadi, B.; Bordbar, M.; Yeganeh-Faal, A.; Nasrollahzadeh, M. Green synthesis of Ag nanoparticles/clinoptilolite using Vaccinium macrocarpon fruit extract and its excellent catalytic activity for reduction of organic dyes. J. Alloys Compd. 2017, 719, 82-88. [CrossRef]

42. Manivasagan, P.; Venkatesan, J.; Senthilkumar, K.; Sivakumar, K.; Kim, S.-K. Biosynthesis, antimicrobial and cytotoxic effect of silver nanoparticles using a novel Nocardiopsis sp. MBRC-1. Biomed. Res. Int 2013. [CrossRef]

43. Karthik, L.; Kumar, G.; Kirthi, A.V.; Rahuman, A.; Rao, K.B. Streptomyces sp. LK3 mediated synthesis of silver nanoparticles and its biomedical application. Bioprocess Biosyst. Eng. 2013, 37, 261-267. [CrossRef]

44. Wei, Y.; Salih, K.A.M.; Lu, S.; Hamza, M.F.; Fujita, T.; Vincent, T.; Guibal, E. Amidoxime Functionalization of Algal/Polyethyleneimine Beads for the Sorption of Sr(II) from Aqueous Solutions. Molecules 2019, 24, 3893. [CrossRef] [PubMed] 
45. Hamza, M.F.; Lu, S.; Salih, K.A.M.; Mira, H.; Dhmees, A.S.; Fujita, T.; Wei, Y.; Vincent, T.; Guibal, E. As(V) sorption from aqueous solutions using quaternized algal/polyethyleneimine composite beads. Sci. Total Environ. 2020, 719, 137396. [CrossRef] [PubMed]

46. Mohammadi, N.; Ganesan, A.; Chantler, C.T.; Wang, F. Differentiation of ferrocene D5d and D5h conformers using IR spectroscopy. J. Organomet. Chem. 2012, 713, 51-59. [CrossRef]

47. Hamza, M.F.; Abdel-Rahman, A.A.-H.; Guibal, E. Magnetic glutamine-grafted polymer for the sorption of U(VI), Nd(III) and Dy(III). J. Chem. Technol. Biotechnol. 2018, 93, 1790-1806. [CrossRef]

48. Wei, Y.; Rakhatkyzy, M.; Salih, K.A.M.; Wang, K.; Hamza, M.F.; Guibal, E. Controlled bi-functionalization of silica microbeads through grafting of amidoxime/methacrylic acid for $\mathrm{Sr}(\mathrm{II})$ enhanced sorption. Chem. Eng. J. 2020, 402, 125220. [CrossRef]

49. Coates, J. Interpretation of infrared spectra, a practical approach. Encyclopedia of analytical chemistry: Applications, theory and instrumentation. Infrared Spectrosc. 2006. [CrossRef]

50. Hamza, M.F.; Aly, M.M.; Abdel-Rahman, A.A.-H.; Ramadan, S.; Raslan, H.; Wang, S.; Vincent, T.; Guibal, E. Functionalization of magnetic chitosan particles for the sorption of U (VI), Cu (II) and Zn (II)—hydrazide derivative of glycine-grafted chitosan. Materials 2017, 10, 539. [CrossRef]

51. Fouda, A.; Salem, S.S.; Wassel, A.R.; Hamza, M.F.; Shahee, T.I. Optimization of green biosynthesized visible light active $\mathrm{CuO} / \mathrm{ZnO}$ nano-photocatalysts for the degradation of organic methylene blue dye. Heliyon 2020, 6, e04896. [CrossRef]

52. El-Naggar, N.E.-A.; Mohamedin, A.; Hamza, S.S.; Sherief, A.-D. Extracellular Biofabrication, Characterization, and Antimicrobial Efficacy of Silver Nanoparticles Loaded on Cotton Fabrics Using Newly Isolated Streptomyces sp. SSHH-1E. J. Nanomater. 2016, 2016, 3257359. [CrossRef]

53. Sastry, M.; Ahmad, A.; Khan, M.I.; Kumar, R. Biosynthesis of metal nanoparticles using fungi and actinomycete. Curr. Sci. 2003, 85, 162-170.

54. Eid, A.M.; Fouda, A.; Niedbata, G.; Hassan, S.E.-D.; Salem, S.S.; Abdo, A.M.; Hetta, H.F.; Shaheen, T.I. Endophytic Streptomyces laurentii Mediated Green Synthesis of Ag-NPs with Antibacterial and Anticancer Properties for Developing Functional Textile Fabric Properties. Antibiotics 2020, 9, 641. [CrossRef] [PubMed]

55. Monowar, T.; Rahman, M.; Bhore, S.J.; Raju, G.; Sathasivam, K.V. Silver nanoparticles synthesized by using the endophytic bacterium Pantoea ananatis are promising antimicrobial agents against multidrug resistant bacteria. Molecules 2018, 23, 3220. [CrossRef]

56. Hamouda, R.A.; Hussein, M.H.; Abo-elmagd, R.A.; Bawazir, S.S. Synthesis and biological characterization of silver nanoparticles derived from the cyanobacterium Oscillatoria limnetica. Sci. Rep. 2019, 9, 1-17. [CrossRef]

57. Vijayabharathi, R.; Sathya, A.; Gopalakrishnan, S. Extracellular biosynthesis of silver nanoparticles using Streptomyces griseoplanus SAI-25 and its antifungal activity against Macrophomina phaseolina, the charcoal rot pathogen of sorghum. Biocatal. Agric. Biotechnol. 2018, 14, 166-171. [CrossRef]

58. Anandalakshmi, K.; Venugobal, J.; Ramasamy, V. Characterization of silver nanoparticles by green synthesis method using Pedalium murex leaf extract and their antibacterial activity. Appl. Nanosci. 2016, 6, 399-408. [CrossRef]

59. Abd-Elnaby, H.M.; Abo-Elala, G.M.; Abdel-Raouf, U.M.; Hamed, M.M. Antibacterial and anticancer activity of extracellular synthesized silver nanoparticles from marine Streptomyces rochei MHM. Egypt. J. Aquat. Res. 2016, 42, 301-312. [CrossRef]

60. Tomaszewska, E.; Soliwoda, K.; Kadziola, K.; Tkacz-Szczesna, B.; Celichowski, G.; Cichomski, M.; Szmaja, W.; Grobelny, J. Detection limits of DLS and UV-Vis spectroscopy in characterization of polydisperse nanoparticles colloids. J. Nanomater. 2013. [CrossRef]

61. Singh, T.; Jyoti, K.; Patnaik, A.; Singh, A.; Chauhan, R.; Chandel, S. Biosynthesis, characterization and antibacterial activity of silver nanoparticles using an endophytic fungal supernatant of Raphanus sativus. J. Genet. Eng. Biotechnol. 2017, 15, 31-39. [CrossRef]

62. Elamawi, R.M.; Al-Harbi, R.E.; Hendi, A.A. Biosynthesis and characterization of silver nanoparticles using Trichoderma longibrachiatum and their effect on phytopathogenic fungi. Egypt. J. Biol. Pest Control 2018, 28, 28. [CrossRef] 
63. Qais, F.A.; Shafiq, A.; Khan, H.M.; Husain, F.M.; Khan, R.A.; Alenazi, B.; Alsalme, A.; Ahmad, I. Antibacterial effect of silver nanoparticles synthesized using Murraya koenigii (L.) against multidrug-resistant pathogens. Bioinorg. Chem. Appl. 2019, 2019. [CrossRef]

64. Manimaran, M.; Kannabiran, K. Actinomycetes-mediated biogenic synthesis of metal and metal oxide nanoparticles: Progress and challenges. Lett. Appl. Microbiol. 2017, 64, 401-408. [CrossRef] [PubMed]

65. Kumar, P.S.; Balachandran, C.; Duraipandiyan, V.; Ramasamy, D.; Ignacimuthu, S.; Al-Dhabi, N.A. Extracellular biosynthesis of silver nanoparticle using Streptomyces sp. 09 PBT 005 and its antibacterial and cytotoxic properties. Appl. Nanosci. 2015, 5, 169-180. [CrossRef]

66. Al-Dhabi, N.A.; Ghilan, A.-K.M.; Esmail, G.A.; Arasu, M.V.; Duraipandiyan, V.; Ponmurugan, K. Environmental friendly synthesis of silver nanomaterials from the promising Streptomyces parvus strain Al-Dhabi-91 recovered from the Saudi Arabian marine regions for antimicrobial and antioxidant properties. J. Photochem. Photobiol. B Biol. 2019, 197, 111529. [CrossRef] [PubMed]

67. Zorraquín-Peña, I.; Cueva, C.; Bartolomé, B.; Moreno-Arribas, M.V. Silver Nanoparticles against Foodborne Bacteria. Effects at Intestinal Level and Health Limitations. Microorganisms 2020, 8, 132. [CrossRef]

68. Pryshchepa, O.; Pomastowski, P.; Buszewski, B. Silver nanoparticles: Synthesis, investigation techniques, and properties. Adv. Colloid Interface Sci. 2020, 284, 102246. [CrossRef]

69. Gordon, O.; Slenters, T.V.; Brunetto, P.S.; Villaruz, A.E.; Sturdevant, D.E.; Otto, M.; Landmann, R.; Fromm, K.M. Silver coordination polymers for prevention of implant infection: Thiol interaction, impact on respiratory chain enzymes, and hydroxyl radical induction. Antimicrob. Agents Chemother. 2010, 54, 4208-4218. [CrossRef]

70. Wypij, M.; Czarnecka, J.; Świecimska, M.; Dahm, H.; Rai, M.; Golinska, P. Synthesis, characterization and evaluation of antimicrobial and cytotoxic activities of biogenic silver nanoparticles synthesized from Streptomyces xinghaiensis OF1 strain. World J. Microbiol. Biotechnol. 2018, 34, 23. [CrossRef]

71. Itani, R.; Al Faraj, A. siRNA Conjugated Nanoparticles-A Next Generation Strategy to Treat Lung Cancer. Int. J. Mol. Sci. 2019, 20, 6088. [CrossRef]

72. Mohmed, A.A.; Fouda, A.; Elgamal, M.S.; Hassan, S.E.-D.; Shaheen, T.I.; Salem, S.S. Enhancing of cotton fabric antibacterial properties by silver nanoparticles synthesized by new egyptian strain fusarium keratoplasticum A1-3. Egypt. J. Chem. 2017, 60, 63-71. [CrossRef]

73. Gudikandula, K.; Charya Maringanti, S. Synthesis of silver nanoparticles by chemical and biological methods and their antimicrobial properties. J. Exp. Nanosci. 2016, 11, 714-721. [CrossRef]

74. Matteis VDe Cascione, M.; Toma, C.; Leporatti, S. Silver Nanoparticles: Synthetic Routes. Vitro Toxicity and Theranostic Applications for Cancer Disease. Nanomaterials 2018, 8, 319. [CrossRef] [PubMed]

75. Nguyen, K.T. Targeted nanoparticles for cancer therapy: Promises and challenge. Nanomed. Nanotechnol. 2011, 2. [CrossRef]

76. Zein, R.; Alghoraibi, I.; Soukkarieh, C.; Salman, A.; Alahmad, A. In-vitro anticancer activity against Caco-2 cell line of colloidal nano silver synthesized using aqueous extract of Eucalyptus Camaldulensis leaves. Heliyon 2020, 6, e04594. [CrossRef] [PubMed]

77. Liao, C.; Li, Y.; Tjong, S.C. Bactericidal and Cytotoxic Properties of Silver Nanoparticles. Int. J. Mol. Sci. 2019, 20, 449. [CrossRef] [PubMed]

78. Salem, S.S.; Fouda, M.M.G.; Fouda, A.; Awad, M.A.; Al-Olayan, E.M.; Allam, A.A.; Shaheen, T.I. Antibacterial, Cytotoxicity and Larvicidal Activity of Green Synthesized Selenium Nanoparticles Using Penicillium corylophilum. J. Clust. Sci. 2020. [CrossRef]

79. Johnson, A.E. The Theory of Coloration of Textiles Society of Dyers and Colourists; Society of Dyers and Colourists: Bradford, UK, 1989.

80. Xing, H.; Cheng, J.; Tan, X.; Zhou, C.; Fang, L.; Lin, J. Ag nanoparticles-coated cotton fabric for durable antibacterial activity: Derived from phytic acid-Ag complex. J. Text. Inst. 2020, 111, 855-861. [CrossRef]

81. Othman, A.M.; Elsayed, M.A.; Al-Balakocy, N.G.; Hassan, M.M.; Elshafei, A.M. Biosynthesis and characterization of silver nanoparticles induced by fungal proteins and its application in different biological activities. J. Genet. Eng. Biotechnol. 2019, 17, 8. [CrossRef]

82. Tang, B.; Li, J.; Hou, X.; Afrin, T.; Sun, L.; Wang, X. Colorful and Antibacterial Silk Fiber from Anisotropic Silver Nanoparticles. Ind. Eng. Chem. Res. 2013, 52, 4556-4563. [CrossRef] 
83. Vukoje, I.; Lazić, V.; Vodnik, V.; Mitrić, M.; Jokić, B.; Phillip Ahrenkiel, S.; Nedeljković, J.M.; Radetić, M. The influence of triangular silver nanoplates on antimicrobial activity and color of cotton fabrics pretreated with chitosan. J. Mater. Sci. 2014, 49, 4453-4460. [CrossRef]

84. Shateri-Khalilabad, M.; Yazdanshenas, M.E.; Etemadifar, A. Fabricating multifunctional silver nanoparticlescoated cotton fabric. Arab. J. Chem. 2017, 10, S2355-S2362. [CrossRef]

Publisher's Note: MDPI stays neutral with regard to jurisdictional claims in published maps and institutional affiliations.

(C) 2020 by the authors. Licensee MDPI, Basel, Switzerland. This article is an open access article distributed under the terms and conditions of the Creative Commons Attribution (CC BY) license (http://creativecommons.org/licenses/by/4.0/). 